\title{
Macroprudential Regulation, Credit Spreads and the Role of
}

\author{
Monetary Policy*
}

William J. Tayler $^{\dagger} \quad$ Roy Zilberman ${ }^{\ddagger}$

August 2016

\begin{abstract}
We study the macroprudential roles of bank capital regulation and monetary policy in a borrowing cost channel model with endogenous financial frictions, driven by credit risk, bank losses and bank capital costs. These frictions induce financial accelerator mechanisms and motivate the examination of a macroprudential toolkit. Following credit shocks, countercyclical regulation is more effective than monetary policy in promoting price, financial and macroeconomic stability. For supply shocks, combining macroprudential regulation with a stronger anti-inflationary policy stance is optimal. The findings emphasize the importance of the Basel III accords in alleviating the output-inflation trade-off faced by central banks, and cast doubt on the desirability of conventional (and unconventional) Taylor rules during periods of financial distress.
\end{abstract}

JEL Classification Numbers: E32, E44, E52, E58, G28

\footnotetext{
${ }^{*}$ We are grateful to the Editor and two anonymous Referees for very helpful comments on a previous draft. We are also thankful to Fabio Verona, Raffaele Rossi, Philipp Pfeiffer (Discussant), Michele Piffer, Paulo Santos Monteiro, Anne Villamil, Frederic Malherbe, Giorgio Motta, David Peel, Keyra Primus, David Chivers and Maurizio Zanardi for helpful comments and discussions. Furthermore, we thank seminar and conference participants at the Bank of England (2016); Midwest Macro Meeting (Purdue University, 2016); Royal Economic Society (RES, University of Sussex, 2016); Graduate School of Economics (Barcelona GSE, 2014); Effective Macroprudential Instruments (University of Nottingham, 2014); Recent Developments in Macroeconomics (ZEW and the University of Mannheim, 2014); Spring Meeting of Young Economists (Vienna University of Economics and Business, 2014); and the 3rd European Conference on Banking and the Economy (ECOBATE, University of Southampton, 2014). Finally, we would like to acknowledge the Bank of England - One Research Committee who awarded an earlier version of this paper the One Bank Research Prize for 2015. The views expressed in this paper, as well as any errors, are our own.

${ }^{\dagger}$ Lancaster University Management School, Department of Economics, United Kingdom, LA14YX. E-Mail: w.tayler@lancaster.ac.uk. Phone: 0044-1524594235.

${ }^{\ddagger}$ Lancaster University Management School, Department of Economics, United Kingdom, LA14YX. E-Mail: r.zilberman@lancaster.ac.uk. Phone: 0044-1524594034.
} 
Keywords: Basel III - Macroprudential Policy, Bank Capital, Monetary Policy, Borrowing Cost Channel, Welfare. 


\section{Introduction}

The global financial crisis of 2007-2009 followed by the Great Recession have emphasized the importance of developing macroeconomic models studying the interactions between the financial system and real economy. In the aftermath of the crisis, it is now clear that restrictions in lending, higher borrowing costs and financial regulation, all of which directly impact the credit markets, have translated into distortions in the wider economy. Subsequently, a growing number of research papers and policy discussions on the role of banking, credit risk and bank capital in the transmission of demand, supply and importantly financial shocks to the real economy have emerged in the past few years. ${ }^{1}$

The general consensus in the literature is that credit market frictions and risk sensitive bank capital regulation (in the form of Basel II) can exacerbate procyclicality in the financial system and real economy (see Covas and Fujita (2010), Liu and Seeiso (2012) and Angeloni and Faia (2013) for Basel II procyclicality). These potential adverse consequences have led to a substantial shift in the policy debate, which now not only focuses on the banks' individual solvency captured by bank adequacy requirements (microprudential policies), but also on the role of macroprudential tools in preventing and managing the build-up of financial imbalances. The new Basel III Accords, set to be fully implemented by 2018, intend to enforce banks to increase the quality of their assets, raise the capital adequacy ratio, hold countercyclical bank capital buffers and set loan loss provisions in a timely manner before credit risk materializes (see Basel Committee of Banking Supervision (BCBS) (2011) for further details). The objectives of the Basel III regulatory measures are to enhance financial stability, encourage more restricted lending in economic booms, mitigate systemic risk and allow the financial sector to better absorb losses associated with an eruption of a negative credit cycle.

Beyond the direct reforms Basel III imposes on the global banking system, can countercyclical bank capital buffers, which rise during economic upturns and thus limit credit growth, also promote overall macroeconomic and price stability? While these objectives are not officially part of the banking regulation agenda (as opposed to protecting the banking sector against future losses), it is clear that with the undeniable link between the financial sector and real economy, banking regulation may have also sizeable macroeconomic effects. The question addressed is whether Basel III-type regulation can contain the negative adverse spillovers flowing from the financial sector to the real economy? In this context, we also need to comprehend the effectiveness of monetary policy rules in achieving price and output stability when credit market frictions and regulatory requirements prevail.

This paper contributes to the growing macrofinance literature by promoting a further understanding on financial-real sector linkages, and examining the welfare implications and interactions between bank capital regulation and monetary policy in a Dynamic Stochastic General Equilibrium (DSGE) model with nominal rigidities, a borrowing cost channel and endogenous financial frictions. These market imperfections include collateralized lending, financial regulation, risk of default at the firm level, and ex-ante commercial bank losses. ${ }^{2}$ The necessity for Basel II type bank capital adequacy requirements is to absorb banking sector losses, which guarantees deposits are repaid in

\footnotetext{
${ }^{1}$ Meh and Moran (2010) and Gerali, Neri, Sessa and Signoretti (2010) examine the role of bank capital in propagating various shocks. Jermann and Quadrini (2012) and Christiano, Motto and Rostagno (2014), on the other hand, focus on the direct effects financial shocks have on the macroeconomy. These authors find that different types of financial shocks are important for explaining the dynamics of real variables.

${ }^{2}$ We use bank losses and default costs in the banking sector interchangeably throughout the paper.
} 
full. At the same time, credit risk induces further bank capital losses, resulting in an increase in the cost of bank capital as well as stricter regulatory requirements (under Basel II), both of which lead to higher borrowing costs. As in Ravenna and Walsh (2006) and De Fiore and Tristani (2013), firms in this setup must borrow from commercial banks to finance their labour costs. Therefore, the refinance rate, bank capital regulation and the various credit market frictions described above (all of which endogenously impact the lending rate and financial market conditions) translate also into changes in the behaviour of the marginal cost, price inflation, wage inflation and output through the borrowing cost channel. ${ }^{3}$ Building on this literature, the borrowing cost channel in our model is enhanced by a richer banking environment, regulatory requirements and various credit frictions, which can explain important links between the financial sector, inflation and the real business cycle. $^{4}$

Compared to the majority of the macrofinance literature, where credit lines are used to finance house purchase and investment in physical capital, we pursue a different approach and indeed introduce loans to finance labour costs. This modeling viewpoint is motivated by recent evidence which suggests that variations in working-capital loans following adverse financial shocks can have persistent negative effects on the economic activity (see Fernandez-Corugedo, McMahon, Millard and Rachel (2011) who estimate the cost channel for the U.K. economy and Christiano, Eichenbaum and Trabandt (2015) who estimate this channel for the U.S.). This result, therefore, requires the examination of macroprudential policies when firms rely on external finance to support their production activities.

The simulated model shows that countercyclical financial regulation (Basel III) is very effective at fostering financial and price stability, whereas credit spread-augmented Taylor rules increase price and wage inflation volatilities, and thus provide zero welfare gains. From a policy perspective we conclude that: a) If the economy is hit by credit shocks, then by setting bank capital requirements responding countercyclically to credit risk, regulatory authorities can achieve the anti-inflation target of monetary policy as well as eliminate welfare losses (comprised of variances in price inflation, the output gap and the wage inflation gap). In this state, the output-price inflation-wage inflation trade-off is minimized and monetary policy rules become redundant since optimal monetary policy suggests leaving the refinance rate unchanged; b) Following technology shocks, aggressive macroprudential regulation can restore a more hawkish stance of monetary policy, which in combination yield the highest welfare gain. Under these conditions, central banks can contribute further to price stability through the standard demand channel of monetary policy without amplifying inflationary pressures via the monetary policy cost channel. Financial distortions, countercyclical regulation and different types of shocks therefore significantly alter the transmission mechanism of monetary

\footnotetext{
${ }^{3}$ Indeed, we refer to this channel as the "borrowing cost channel" and not the standard "cost channel of monetary transmission" as is common in this literature. The "cost channel of monetary policy", affected by changes in the policy rate, is only part of the wider "borrowing cost channel", which in our model is driven mostly by regulatory requirements and credit market frictions.

${ }^{4}$ In a recent contribution which abstracts from credit default risk, De Paoli and Paustian (2013) also use the borrowing cost channel (loans for working-capital needs) to study the optimal interaction between macroprudential regulation (defined by a cyclical tax on the borrowing of firms) and monetary policy under discretion and commitment. We instead focus on optimal simple implementable rules, with monetary policy defined by a Taylor rule, and macroprudential regulation operated through countercyclical bank capital requirements. See also Agénor and Pereira da Silva (2014) who examine the interaction between macroprudential policy (in the form of cyclical required reserves) and monetary policy within a simple deterministic macro model featuring a cost channel.
} 
policy and its optimal behaviour.

This paper is also related to the following strands of literature. First, it contributes to Agénor and Aizenman (1998) and its New Keynesian counterpart framework developed in Agénor, Bratsiotis and Pfajfar (2014), by introducing a rationale for bank capital (and explicitly modeling its costs), ex-ante default costs in the banking sector, financial risk shocks originating in the banking system, countercyclical bank capital regulation and a credit spread-augmented type monetary policy rule. More specifically, we evaluate optimal macroprudential and monetary policy rules in a simple framework capable of generating a negative relationship between the loan rate spread and GDP, without relying on the costly state verification mechanism and borrowers' net worth used in the Bernanke, Gertler and Gilchrist (1999) financial accelerator type models. ${ }^{5}$ In fact, the additional financial imperfections and Basel II type regulatory rules introduced in our model amplify the countercyclical correlation between output and borrowing costs, and induce further financial accelerator effects via the borrowing cost channel. The relatively small scale nature of our setup also allows us to clearly disentangle and intuitively demonstrate the different transmission mechanisms linking the credit market conditions to the macroeconomy, and to explain the implications for optimal simple policy rules and welfare.

Second, this paper relates to recent contributions that have studied the interaction between macroprudential regulation and monetary policy in macroeconomic models. For example, in a simple monetary model with financial elements, N'Diaye (2009) shows that countercyclical regulation can support monetary policy in mitigating output fluctuations while maintaining financial stability. In some DSGE contributions, Kannan, Rabanal and Scott (2012), Angelini, Neri and Panetta (2014), Rubio and Carrasco-Gallego (2014) and Angeloni and Faia (2013) illustrate that depending on the nature of the shock, a combination of a credit-augmented Taylor rule together with a Basel III type countercyclical rule, may be optimal in minimizing welfare losses. Moreover, Suh (2014) demonstrates that macroprudential policy affecting directly the financial market conditions has a limited impact on prices as opposed to monetary policy. Contributing to these models, we employ a rich borrowing cost channel with endogenous credit spreads, which highlights the importance of Basel III in promoting financial, price and macroeconomic stability, as well as the welfare detrimental aspects of conventional and unconventional monetary policy rules. In this sense, our model supports the more 'conventional' view, wherein monetary policy should not 'lean against the credit cycle' or respond to financial imbalances (as also advocated in the seminal paper of Bernanke and Gertler (2001)). Nevertheless, within this borrowing cost channel framework featuring endogenous credit risk, as opposed to models where non-risky loans are provided to finance house purchases (Gelain, Lansing and Mendicino (2013), and Rubio and Carrasco-Gallego (2016)), macroprudential regulation considerably alleviates the standard trade-offs faced by central banks. ${ }^{6}$ In other words, optimal banking regulation needs not to be in conflict with monetary policy when the goal is to achieve financial, output and price stability. This result is a key difference between our paper and the ones described above, and highlights how a well-designed countercyclical rule can insulate the

\footnotetext{
${ }^{5}$ Most empirical evidence show a strong negative relationship between loan rate spreads and GDP fluctuations (see Nolan and Thoenissen (2009) and Gerali, Neri, Sessa and Signoretti (2010) for example).

${ }^{6}$ Welfare in our model is based on an analytical second order approximation of the representative household's utility function such that central bank losses consist of price inflation, output gap and wage inflation volatilities. In other words, financial stability objectives do not directly enter the welfare function which excludes entrepreneurs and the commercial bank's utilities. Nevertheless, financial frictions have a significant impact on the real and nominal variables so a macroprudential type regulatory policy targeting financial stability (measured in terms of credit risk and credit spreads in this model) can essentially achieve superior welfare outcomes.
} 
real economy from the adverse spillovers flowing from the financial sector, especially following more empirically-relevant financial shocks. ${ }^{7}$

Third, following financial shocks, driven by uncertainty about the banks ability to recover collateral from defaulting firms, we obtain a significant trade-off between output and inflation, supporting De Fiore and Tristani (2013) and Gilchrist, Schoenle, Sim and Zakrajsek (2016). In the latter, financially weak firms are more likely to increase prices during a crisis period in an attempt to maintain cash flows, leading to a rise in aggregate inflation and violating the so called 'divine coincidence' of monetary policy. ${ }^{8}$ In the borrowing cost channel framework of De Fiore and Tristani (2013), an aggressive easing of monetary policy (under commitment) is optimal in response to adverse financial shocks. Unlike their model, we generate a countercyclical loan rate spread regardless of the type of shock (more consistent with the data as explained above). Additionally, instead of characterizing a fully optimal (Ramsey) monetary policy, we study how credit market frictions and Basel III type rules interact with simple standard and credit spread-augmented Taylor rules, and compute the optimal policy combination which minimizes welfare losses and essentially promotes financial stability. To the best of our knowledge, this paper is a first attempt to model the interplay between bank capital, countercyclical regulation and the role of standard and augmented monetary policy in a DSGE model with a borrowing cost channel altered by meaningful endogenous financial imperfections.

This paper proceeds as follows. Section 2 presents the model. Section 3 details the equilibrium properties and parameterization of the model. In Section 4 we examine simple and implementable optimal policy rules which minimize a micro-founded welfare loss function. Section 5 concludes.

\section{The Model}

The economy consists of households, a final good (FG) firm, intermediate good (IG) firms, competitive commercial banks and a central bank, which also acts as the financial regulator. At the beginning of the period and following the realization of aggregate shocks, the representative bank receives deposits from households, issues bank capital, and sets the loan rate based on the refinance rate, bank capital requirements, the risk premium and the probability of obtaining the IG firms' collateral seized in the case of default. ${ }^{9}$ For a given loan rate, the IG firms decide on the level of employment, prices and loans, with the latter used to fund wage payments to households. Con-

\footnotetext{
${ }^{7}$ Clerc, Derviz, Mendicino, Moyen, Nikolov, Stracca, Suarez and Vardoulakis (2015) build a larger scale DSGE model with three layers of default and find an optimal bank capital ratio in steady state which exceeds the Basel II 8 percent Cooke ratio. Compared to their model, we focus on optimal bank capital dynamics following financial and technology shocks, and examine the interaction between optimal bank capital rules and monetary policy rules - a feature which is absent from the above paper. Furthermore, the smaller scale version of our model allows us to disentangle the main transmission channels linking the financial sector to the real economy, and to emphasize the welfare implication of optimal simple bank capital and monetary policy rules in a setup featuring credit risk.

${ }^{8}$ In the financial accelerator models which operate through investment demand, output and inflation exhibit a strong co-movement (apart from cost push shocks). Thus, lowering the policy rate can simultaneously stabilize both output and inflation.

${ }^{9}$ As bank capital prices and dividend policies resulting from changes in the price of equity are not modeled in this framework, bank capital in our model is treated more like bank debt rather than equity. In the Basel terminology, bank capital in this model therefore consists of "tier 2" capital and not "tier 1" capital, which consists of equity stock and retained earnings. Nevertheless, there is still an ongoing debate on whether under the new Basel III regulatory rules, banks would also be allowed to hold capital in the form of loss-absorbing debt such as contingent convertible bonds.
} 
currently, households choose the level of consumption, deposits and bank capital given their total income. At the end of the period, the idiosyncratic shocks and hence the firms who default are revealed. As loans are risky, the IG firms pledge output as collateral, which can be seized by the lender in a default scenario. In these bad states of nature, there is also a possibility that the break even bank does not recover any collateral and makes a loss. At the aggregate level, bank capital covers for these losses, which are also endogenously related to the firms' credit risk. Furthermore, households, acting as bank capital holders, know the aggregate state of the economy and can calculate ex-ante banking sector losses. They account for these default costs by demanding a higher return on bank capital such that they are indifferent between holding risk free deposits and bank capital. We now turn to describe in more detail the behaviour of each agent in the economy.

\subsection{Households}

There is a continuum of households, indexed by $i \in(0,1)$, who consume, hold deposits, demand bank capital and supply differentiated labour to a labour aggregator. The objective of each household $i$ is to maximize the following utility function,

$$
U_{i, t}=\mathbb{E}_{i, t} \sum_{s=0}^{\infty} \beta^{s}\left\{\frac{C_{t+s}^{1-\varsigma^{-1}}}{1-\varsigma^{-1}}-\frac{H_{i, t+s}^{1+\gamma}}{1+\gamma}\right\},
$$

where $\mathbb{E}_{i, t}$ is the expectations operator, $\beta \in(0,1)$ the discount factor, $\varsigma$ the intertemporal elasticity of substitution in consumption, and $\gamma$ the inverse of the Frisch elasticity of labour supply. The term $C_{t}$ denotes consumption at time $t$, while $H_{i, t}$ is the time- $t$ hours worked by household $i$.

Households enter period $t$ with real cash holdings of $M_{t}$. They receive their subsidized wage bill $\left(1+\tau_{w}\right)\left(W_{i, t} / P_{t}\right) H_{i, t}$, paid by the IG firm via the labour aggregator, in the form of cash at the beginning of the period, with $W_{i, t}$ denoting the nominal wage, $P_{t}$ the price of the final good, and $\tau_{w}$ the subsidy rate. The cash is then used to make deposits $D_{t}$ at the bank, and for investment in bank capital $V_{t}$ (in real terms). The households remaining cash balances of $M_{t}+$ $\left(1+\tau_{w}\right)\left(W_{i, t} / P_{t}\right) H_{i, t}-D_{t}-V_{t}$ become available to purchase consumption goods subject to a cash-in-advance constraint, $C_{t} \leq M_{t}+\left(1+\tau_{w}\right)\left(W_{i, t} / P_{t}\right) H_{i, t}-D_{t}-V_{t}$. At the end of the period, households receive all real profit income from the financial intermediation process $\left(J_{t}^{F I}\right)$, and aggregate profits from IG firms $\left(J_{t}^{I G}=\int_{0}^{1} J_{j, t}^{I G} d j\right) .{ }^{10}$ Furthermore, households earn gross interest payments on deposits and bank capital, denoted by $R_{t}^{D}$ and $\left(1-\xi_{t}^{V}\right) R_{t}^{V}$, respectively. The term $\xi_{t}^{V}$ denotes the bank capital risk premium, which is derived endogenously later in the text, but taken as given in the household's optimization problem. The real value of cash carried over to period $t+1$ is, ${ }^{11}$

$$
M_{t+1} \frac{P_{t+1}}{P_{t}}=M_{t}+\left(1+\tau_{w}\right) \frac{W_{i, t}}{P_{t}} H_{i, t}-C_{t}-D_{t}-V_{t}+R_{t}^{D} D_{t}+\left(1-\xi_{t}^{V}\right) R_{t}^{V} V_{t}+J_{t}^{F I}+\int_{0}^{1} J_{j, t}^{I G} d j
$$

With a positive deposit rate $\left(R_{t}^{D}>1\right)$, and taking wages and prices as given, the first order

\footnotetext{
${ }^{10}$ Profits from the FG firm are equal to zero.

${ }^{11}$ The timing of the model follows closely Ravenna and Walsh (2006).
} 
conditions with respect to $C_{t}, D_{t}$ and $V_{t}$ can be summarized as,

$$
\begin{gathered}
C_{t}^{-\varsigma^{-1}}=\beta \mathbb{E}_{t} R_{t}^{D} \frac{P_{t}}{P_{t+1}} C_{t+1}^{-\varsigma^{-1}}, \\
R_{t}^{V}=\frac{R_{t}^{D}}{\left(1-\xi_{t}^{V}\right)} .
\end{gathered}
$$

Equation (3) is the standard Euler equation determining the optimal consumption path. Equation (4) is the no-arbitrage condition, relating the rate of return on bank capital to the risk free deposit rate. In equilibrium, the interest rate on bank capital is set as a premium over the deposit rate due to the ex-ante default costs in the banking sector $\left(\xi_{t}^{V}\right) .{ }^{12}$

The wage setting environment follows closely Erceg, Henderson and Levin (2000), and Christiano, Eichenbaum and Evans (2005), where each household $i$ supplies a unique type of labour $\left(H_{i, t}\right)$ with $i \in(0,1)$. All these types of labour are then aggregated by a competitive labour contractor into one composite homogenous labour $\left(N_{t}\right)$ using the standard Dixit-Stiglitz (1977) technology, $N_{t}=\left(\int_{0}^{1} H_{i, t}^{\frac{\lambda_{w}-1}{\lambda_{w}}} d i\right)^{\frac{\lambda_{w}}{\lambda_{w}-1}}$, with $\lambda_{w}>1$ representing the constant elasticity of substitution between the different types of labour. The $i^{t h}$ household therefore faces a demand curve for its labour, $H_{i, t}=\left(W_{i, t} / W_{t}\right)^{-\lambda_{w}} N_{t}$, where $W_{t}$ denotes the aggregate nominal wage paid for one unit of the composite labour. The zero profit condition for the labour aggregator yields the economy wide wage equation, $W_{t}=\left[\int_{0}^{1} W_{i, t}^{1-\lambda_{w}} d i\right]^{\frac{1}{1-\lambda_{w}}}$. Calvo (1983)-type nominal rigidities are assumed such that in each period a constant fraction of $1-\omega_{w}$ workers are able to re-optimize their wages while a fraction of $\omega_{w}$ index their wages according to last period's price inflation rate $\left(\pi_{t-1}\right)$. These non re-optimizing households therefore set their wages according to $W_{i, t}=\pi_{t-1} W_{i, t-1}$. Moreover, if wages have not been set since period $t$, then at period $t+s$ the real relative wage for household $i$ becomes $\left(W_{i, t+s} / W_{t+s}\right)=\Pi^{s} W_{i, t} / W_{t+s}$, where $\Pi^{s}=\pi_{t} \times \pi_{t+1} \times \ldots \times \pi_{t+s-1}$. Consequently, the demand for labour in period $t+s$ is $H_{i, t+s}=\left(\Pi^{s} W_{i, t} / W_{t+s}\right)^{-\lambda_{w}} N_{t+s}$. In equilibrium all reoptimizing households choose the same wage $\left(W_{t}^{*}\right)$, and the optimal relative wage in a log-linearized form (denoted by 'hat') is given by $\left(\widehat{W}_{t}^{*} / W_{t}\right)=\left[\omega_{w} /\left(1-\omega_{w}\right)\right] \widehat{\pi}_{t}^{W}$, with $\widehat{\pi}_{t}^{W} \equiv \widehat{W}_{t}-\widehat{W}_{t-1}$ denoting the wage inflation. In the absence of wage rigidities $\left(\omega_{w}=0\right)$, the subsidized real wage equals to the wage mark-up $\left[\lambda_{w} /\left(\lambda_{w}-1\right)\right]$ multiplied by the marginal rate of substitution between leisure and consumption $\left(M R S_{t}\right) ;\left(1+\tau_{w}\right)\left(W_{t} / P_{t}\right)=\left[\lambda_{w} /\left(\lambda_{w}-1\right)\right] M R S_{t}$, where $M R S_{t}=N_{t}^{\gamma} C_{t}^{\frac{1}{\varsigma}}$ and $N_{t}=H_{t}$. Employment is subsidized in order to eliminate the positive mark-up associated with the monopolistic wage setting; $\left(1+\tau_{w}\right)=\lambda_{w} /\left(\lambda_{w}-1\right)$. In this way, the steady state of the model satisfies $(W / P)=M R S$, as in a perfectly competitive economy. ${ }^{13,14}$

\footnotetext{
${ }^{12}$ Markovic (2006) also derives a no-arbitrage condition between the bank capital rate and the risk free rate, with the mark-up depending on an exogenously given risk of default (among other variables). In our model, the expected default costs in the banking sector, which determine the bank capital - deposit rate spread, are endogenous with respect to both the risk of default at the firm level and the bank capital to loan ratio.

${ }^{13}$ The full derivation of the wage setting environment is available upon request.

${ }^{14}$ Steady state values are denoted by dropping the time subscript.
} 
Finally, as in Erceg, Henderson and Levin (2000), the wage inflation equation is shown to satisfy,

$$
\widehat{\pi}_{t}^{W}=\beta E_{t} \widehat{\pi}_{t+1}^{W}+\frac{\left(1-\omega_{w}\right)\left(1-\beta \omega_{w}\right)}{\left(\omega_{w}\right)\left(1+\gamma \lambda_{w}\right)}\left[\widehat{M R S}_{t}-\widehat{W}_{t}^{R}\right]
$$

where real wages evolve according to,

$$
\widehat{W_{t}^{R}} \equiv \widehat{\left(\frac{W_{t}}{P_{t}}\right)}=\widehat{W_{t-1}^{R}}+\widehat{\pi}_{t}^{W}-\widehat{\pi}_{t}^{P}
$$

with $\widehat{\pi}_{t}^{P} \equiv \widehat{P}_{t}-\widehat{P}_{t-1}$ representing the log-linearized price inflation rate as a deviation from its steady state. The motivation for including sticky wages is threefold: First, sticky wages are necessary to match the sluggish and persistent behaviour of real wages observed in data, and are important for obtaining a persistent response of inflation without relying on implausible values for price stickiness (as in Christiano, Eichenbaum and Evans (2005)). Second, wage stickiness is crucial for obtaining implementable optimal policy rules following supply shocks, which would otherwise produce abnormally high optimal inflation coefficient weights in the Taylor rule (see Schmitt-Grohé and Uribe (2007)). Given that this paper examines implementable optimal policy rules and their interactions with one another, there is an appeal in having a benchmark optimal inflation coefficient within an unbounded reasonable range. Third, as recently documented by Debortoli, Kim, Lindé, and Nunes (2015), a central bank loss function incorporating a nominal wage inflation gap (as present in this paper) provides a better approximation to the true household's welfare function than a simple standard output gap-inflation based objective.

\subsection{Final Good Firm}

A perfectly competitive representative FG firm assembles a continuum of intermediate goods $\left(Y_{j, t}\right.$ with $j \in(0,1)$ ), to produce final output $\left(Y_{t}\right)$ using the standard Dixit-Stiglitz (1977) technology, $Y_{t}=\left(\int_{0}^{1} Y_{j, t}^{\frac{\lambda_{p}-1}{\lambda_{p}}} d j\right)^{\frac{\lambda_{p}}{\lambda_{p}-1}}$, where $\lambda_{p}>1$. Given the IG price $P_{j, t}$, the demand function for each intermediate good is $Y_{j, t}=Y_{t}\left(\frac{P_{j, t}}{P_{t}}\right)^{-\lambda}$ with the aggregate price index $P_{t}=\left(\int_{0}^{1} P_{j, t}^{1-\lambda} d j\right)^{\frac{1}{1-\lambda}}$.

\subsection{Intermediate Good Firms}

Each IG firm $j \in(0,1)$ uses the homogeneous labour supplied by the labour contractor, and faces the following linear production function,

$$
Y_{j, t}=Z_{j, t} N_{j, t}, \quad Z_{j, t}=A_{t} \varepsilon_{j, t}^{F},
$$

where $N_{j, t}$ and $Z_{j, t}$ are the amount of homogeneous labour employed and the total productivity shock experienced by firm $j$, respectively. The term $A_{t}$ denotes a mean one, common economy wide technology shock, which follows the $A R(1)$ process: $A_{t}=(A)^{1-\varsigma^{A}}\left(A_{t-1}\right)^{\varsigma^{A}} \exp \left(\alpha_{t}^{A}\right)$, where $\varsigma^{A}$ is the autoregressive coefficient and $\alpha_{t}^{A}$ is a normally distributed random shock with zero mean and a constant variance. The expression $\varepsilon_{j, t}^{F}$ represents an idiosyncratic shock with a constant variance 
distributed uniformly over the interval $\left(\underline{\varepsilon}^{F}, \bar{\varepsilon}^{F}\right) \cdot{ }^{15}$

As in Ravenna and Walsh (2006), the IG firm must borrow from a representative bank in order to pay households wages in advance. Let $L_{j, t}$ be the amount borrowed by firm $j$, then the (real) financing constraint equals to,

$$
L_{j, t}=W_{t}^{R} N_{j, t} .
$$

Financing labour costs bears risk and in case of default the commercial bank expects to seize firm's output $\left(Y_{j, t}\right)$ with a probability of $\chi_{t}$. In these bad states of nature, there is also a possibility of $\left(1-\chi_{t}\right)$ that the bank cannot recover the IG firm's collateral and therefore makes a loss (similar to Jermann and Quadrini (2012)). The term $\chi_{t}$ is assumed to follow the $A R(1)$ shock process: $\chi_{t}=(\chi)^{1-\varsigma^{\chi}}\left(\chi_{t-1}\right)^{\varsigma^{\chi}} \exp \left(\alpha_{t}^{\chi}\right)$, where $\chi \in(0,1)$ denotes the steady state value of this probability, $\varsigma^{\chi}$ is the degree of persistence, and $\alpha_{t}^{\chi}$ is a random shock with a normal distribution and a constant variance. A shock to the probability of recovering collateral $\left(\chi_{t}\right)$ represents a financial (credit) shock in this model, as it directly affects the value of collateralized output the bank can seize in case of default, firms' credit risk and consequently credit spreads.

In the good states of nature, each firm pays back the bank principal plus interest on the loans granted. Consequently, and in line with the willingness to pay approach to debt contracts, default occurs when the expected value of seizable output $\left(\chi_{t} Y_{j, t}\right)$ is less then the amount that needs to be repaid to the lender at the end of the period: $\chi_{t} Y_{j, t}<R_{t}^{L} L_{j, t}$, where $R_{t}^{L}$ denotes the interest rate on loans granted to IG firms. ${ }^{16}$ Using equations (7) and (8), the cut-off value $\left(\varepsilon_{j, t}^{F, M}\right)$ below which the IG firm defaults is,

$$
\varepsilon_{j, t}^{F, M}=\frac{1}{\chi_{t} A_{t}} R_{t}^{L} W_{t}^{R}
$$

Therefore, the threshold value is related to the lending rate, aggregate technology shocks and the real wages and is identical across all firms. However, in our model, the loan rate not only depends on the risk free rate and the finance premium (as in Agénor and Aizenman (1998) and Agénor, Bratsiotis and Pfajfar (2014)), but also on the probability of the bank recovering collateral (credit risk shocks), the total unit costs of bank capital, and the bank capital-loan ratio (as shown in subsequent sections). Hence, both the loan rate and probability of default are affected by the nature of the regulatory regime. Given the uniform properties of $\varepsilon_{t}^{F}$, an explicit closed-form solution

\footnotetext{
${ }^{15}$ We use the uniform distribution in order to generate plausible data-consistent steady state risk of default and loan rate spreads as explained in the parameterization section. This simple distribution also allows for a closed-form expression for credit risk. See also Faia and Monacelli (2007) who adopt a similar approach.

${ }^{16}$ Similar to Agénor and Aizenman (1998), we assume for simplicity that no IG firm defaults if the economy is at the good state of nature and the level of output is sufficiently high to cover for the loan repayment. Furthermore, $\chi_{t}$ can also be interpreted as the fraction of collateral seized by the bank in the default state of nature, net of state verification costs. Alternatively, the default condition can be re-arranged as $\left(1-\chi_{t}\right) Y_{j, t}>Y_{j, t}-R_{t}^{L} L_{j, t}$. That is, the borrower (IG firm) can 'run away' with its' non-collateralized assets and if it does, it can only take $\left(1-\chi_{t}\right) Y_{j, t}$. Hence, if the value of the IG firm's assets after running away is larger than what it would obtain by not running away, then it would be optimal for the IG firm to default. In this way, $\chi_{t}$ affects the incentives of the borrower directly. Specifically, in our model the IG firm internalizes that the bank may not be able to retrieve some of the pledged collateral and decides to default only when the expected level of seized output is lower than the financing costs. In that sense, $\left(1-\chi_{t}\right)$ may be thought of as the probability of the IG firm running away with its collateral. With either interpretation, $\chi_{t}$ as a financial shock enters the model identically.
} 
for the probability of default is given by,

$$
\Phi_{t}=\int_{\underline{\varepsilon}^{F}}^{\varepsilon_{t}^{F, M}} f\left(\varepsilon_{t}^{F}\right) d \varepsilon_{t}^{F}=\frac{\varepsilon_{t}^{F, M}-\underline{\varepsilon}^{F}}{\bar{\varepsilon}^{F}-\underline{\varepsilon}^{F}} .
$$

The IG firm solves a two stage pricing decision problem as soon as the aggregate shocks in period $t$ are realized. In the first stage, each IG producer minimizes the cost of employing labour, taking its (real) effective costs $\left(R_{t}^{L} W_{t}^{R}\right)$ as given. This minimization problem yields the real marginal cost, ${ }^{17}$

$$
m c_{j, t}=\left(R_{t}^{L} W_{t}^{R}\right) / Z_{j, t} .
$$

In the second stage, each IG producer chooses the optimal price for its good. Here Calvo (1983)type contracts are assumed, where a portion of $\omega_{p}$ firms keep their prices fixed while a portion of $1-\omega_{p}$ firms adjust prices optimally given the going marginal cost and the loan rate (set at the beginning of the period). Solving the standard IG firm's problem yields the familiar form of the log-linear New Keynesian Phillips Curve (NKPC),

$$
\widehat{\pi}_{t}^{P}=\beta E_{t} \widehat{\pi}_{t+1}^{P}+\frac{\left(1-\omega_{p}\right)\left(1-\omega_{p} \beta\right)}{\omega_{p}} \widehat{m c}_{t}
$$

In this model, the marginal cost is determined directly by the cost of borrowing from the bank (from 11). Therefore, monetary policy, bank capital, credit risk and the regulatory regime, all of which impact the loan rate as shown in the next sections, have also a direct effect on the marginal cost and accordingly on the rate of price inflation, wage inflation and output. To fix ideas, we refer to the channel which links between the loan rate, marginal cost, inflation and output as the borrowing cost channel.

\subsection{The Banking Sector}

\subsubsection{Lending Rate Decision}

Consider a continuum of perfectly competitive representative banks indexed by $k \in(0,1)$, who raise funds through deposits $\left(D_{t}\right)$, bank capital $\left(V_{t}\right)$ and a liquidity injection $\left(X_{t}\right)$ from the central bank in order to supply credit $\left(L_{t}\right)$ to a continuum of firms. The balance in real terms is therefore, ${ }^{18}$

$$
L_{t}=D_{t}+V_{t}+X_{t}
$$

where $L_{t} \equiv \int_{0}^{1} L_{k, t} d k$ is the aggregate lending to IG firms.

Each bank $k$ expects to break even from its intermediation activity such that the expected income from lending to a continuum of IG firms is equal to the total costs of borrowing deposits

\footnotetext{
${ }^{17}$ Below we show that the bank sets the loan rate based on the IG firm's default decision and threshold default value. Therefore, the risk of default has also a direct effect on the IG firms marginal cost through its endogenous impact on the cost of borrowing.

${ }^{18}$ The aggregate lending from the banking sector is given by $\int_{0}^{1} L_{k, t} d k$, where each bank $k$ lends to contiumn of firms with identical loan demands. Because loans are identical for all banks the $k$ subscript can be dropped.
} 
and bank capital from households, and the cost of receiving liquidity from the central bank, ${ }^{19}$

$$
\int_{\varepsilon_{j, t}^{F, M}}^{\bar{\varepsilon}^{F}}\left[R_{t}^{L} L_{j, t}\right] f\left(\varepsilon_{j, t}^{F}\right) d \varepsilon_{j, t}^{F}+\int_{\underline{\varepsilon}^{F}}^{\varepsilon_{j, t}^{F, M}}\left[\chi_{t} Y_{j, t}\right] f\left(\varepsilon_{j, t}^{F}\right) d \varepsilon_{j, t}^{F}=R_{t}^{V} V_{t}+R_{t}^{D}\left(D_{t}+X_{t}\right)+c V_{t},
$$

where $f\left(\varepsilon_{j, t}^{F}\right)$ is the probability density function of $\varepsilon_{j, t}^{F}$. The first element on the left hand side is the repayment to the bank in the non-default states, while the second element is the expected return to the bank in the default states accounted for the probability of collateral recovery $\left(\chi_{t}\right) .{ }^{20}$ The expression $R_{t}^{V} V_{t}+R_{t}^{D}\left(D_{t}+X_{t}\right)$ is the total return to households and the central bank for providing funds to the bank. Furthermore, the bank faces a linear cost function when issuing bank capital, captured by the term $c V_{t}$, with $c>0$. These costs are independent of the state of the economy and reflect steady administrative costs associated with underwriting or issuing brochures for example. They can also be interpreted as an additional tax on bank capital resembling a tax advantage of debt over equity (not explicitly modeled here), which increases the spread between the overall cost of capital $\left(R_{t}^{V}+c\right)$ and the rate on deposits $\left(R_{t}^{D}\right)$. Following the derivation of the loan rate and the bank capital risk premia, we discuss in more detail why including these costs are important in this framework.

Turning now to the derivation of the lending rate note that,

$$
\int_{\varepsilon_{j, t}^{F, M}}^{\bar{\varepsilon}^{F}}\left[R_{t}^{L} L_{j, t}\right] f\left(\varepsilon_{j, t}^{F}\right) d \varepsilon_{j, t}^{F} \equiv \int_{\underline{\varepsilon}^{F}}^{\bar{\varepsilon}^{F}}\left[R_{t}^{L} L_{j, t}\right] f\left(\varepsilon_{j, t}^{F}\right) d \varepsilon_{j, t}^{F}-\int_{\underline{\varepsilon}^{F}}^{\varepsilon_{j, t}^{F, M}}\left[R_{t}^{L} L_{j, t}\right] f\left(\varepsilon_{j, t}^{F}\right) d \varepsilon_{j, t}^{F},
$$

where $\int_{\underline{\varepsilon}^{F}}^{\bar{\varepsilon}^{F}}\left[R_{t}^{L} L_{j, t}\right] f\left(\varepsilon_{j, t}^{F}\right) d \varepsilon_{j, t}^{F} \equiv R_{t}^{L} L_{j, t}$. Using equations (13), (9) for $\chi_{t}\left(A_{t} \varepsilon_{j, t}^{F, M}\right) N_{j, t}=R_{t}^{L} L_{j, t}$, (7), and dividing by $L_{j, t}$ yields,

$$
R_{t}^{L}=\left(R_{t}^{V}+c\right)\left(\frac{V_{t}}{L_{j, t}}\right)+\left(R_{t}^{D}\right)\left(1-\frac{V_{t}}{L_{j, t}}\right)+\frac{\int_{\underline{\varepsilon}^{F}}^{\varepsilon_{j, t}^{F, M}}\left[\varepsilon_{j, t}^{F, M}-\varepsilon_{j, t}^{F}\right] \chi_{t} A_{t} N_{j, t} f\left(\varepsilon_{j, t}^{F}\right) d \varepsilon_{j, t}^{F}}{L_{j, t}} .
$$

Real wages and the amount of labour employed are identical for each firm and therefore the volume of lending by each bank is also the same. Thus, the subscript $j$ is dropped in what follows. Defining $\Delta_{t} \equiv V_{t} / L_{t}$ as the total bank capital-loan ratio, equation (15) reduces to,

$$
R_{t}^{L}=\nu_{t}\left[\Delta_{t}\left(R_{t}^{V}+c\right)+\left(1-\Delta_{t}\right) R_{t}^{D}\right]
$$

where $\nu_{t} \equiv\left[1-\frac{\int_{\varepsilon^{F}}^{\varepsilon_{t}^{F, M}}\left[\varepsilon_{t}^{F, M}-\varepsilon_{t}^{F}\right] f\left(\varepsilon_{t}^{F}\right) d \varepsilon_{t}^{F}}{\varepsilon_{t}^{F, M}}\right]^{-1}>1$ is defined as the finance premium.

\footnotetext{
${ }^{19}$ The extra liquidity provided by the central bank can also be thought of as a central bank loan paid back at the risk free deposit rate. Nevertheless, introducing a liquidity injection is simply to allow the markets to clear (as in Ravenna and Walsh (2006) and in the rest of the cost channel literature). In this model, the commercial bank is indifferent between borrowing deposits from households and receiving a central bank loan such that the loan rate pricing decision is unaffected.

${ }^{20}$ Recall that with probability $\left(1-\chi_{t}\right)$ the bank receives no collateral in the bad states of nature and therefore makes a loss. However, at the aggregate level and ex-post, the banking sector profits are equal to zero.
} 


\subsubsection{The Bank Capital Risk Premium Rate}

The premium on a unit of bank capital $\left(\xi_{t}^{V}\right)$ determines the mark-up of the bank capital rate over the risk free deposit rate in the household's no-arbitrage condition (equation 4). As explained earlier, commercial banks set the loan rate in each period to the expected break even level. This implies that the price of loans is determined by the cost of deposits and bank capital, adjusted for the risk premium and the bank capital-loan ratio. Additionally, a fraction $\left(1-\chi_{t}\right)$ of banks suffer a loss due to their inability to retrieve collateral from defaulting firms.

Households, who invest bank capital in all banks, know the aggregate level of firm default and are able to calculate aggregate ex-ante losses in the banking sector. ${ }^{21}$ Accounting for bank losses, that translate into bank capital default, ensures that deposits are a safe asset. The decision for households therefore involves calculating the bank capital ex-ante default rate such that the no-arbitrage condition (given by equation 4) is satisfied. Specifically,

$$
\xi_{t}^{V} R_{t}^{V} V_{t}=\left(1-\chi_{t}\right)\left[\int_{\underline{\varepsilon}^{F}}^{\varepsilon_{j, t}^{F, M}}\left[\chi_{t} Y_{j, t}\right] f\left(\varepsilon_{j, t}^{F}\right) d \varepsilon_{j, t}^{F}\right] .
$$

Identity (17) guarantees that the total losses on bank capital $\left(\xi_{t}^{V} R_{t}^{V} V_{t}\right)$ are equal to the value of collateral the banks expected to earn if they were able to retrieve $\chi_{t} Y_{j, t}$ in the default states of nature, weighted by the probability of being a loss-incurring bank $\left(1-\chi_{t}\right) \cdot{ }^{22}$ Combining and substituting equations (7), (8) and (9) and using the properties of the uniform distribution in (17) results in the risk premium required for holding bank capital,

$$
\xi_{t}^{V}=\left(1-\chi_{t}\right) \frac{L_{t}}{V_{t}} \frac{R_{t}^{L}}{R_{t}^{V}}\left(\frac{\varepsilon_{t}^{F, M}+\underline{\varepsilon}^{F}}{2 \varepsilon_{t}^{F, M}}\right) \Phi_{t} .
$$

The bank capital premium rate is a function of the cost of default, $\left(1-\chi_{t}\right) \frac{\left(R_{t}^{L} / R_{t}^{V}\right)}{\left(V_{t} / L_{t}\right)}\left(\frac{\varepsilon_{t}^{F, M}+\varepsilon^{F}}{2 \varepsilon_{t}^{F, M}}\right) \Phi_{t}$, which stems from the possibility of banks making a loss in the states of nature where firms default on their credit. The bank capital risk premium also depends negatively on the bank capital-loan ratio, which, in turn, is determined by the regulatory requirements. The upshot is that the funds raised through the premium on bank capital are necessary to guarantee that all loss-incurring banks are able to honour their commitment towards all depositors, whilst households are indifferent between investing in bank capital and deposits.

\footnotetext{
${ }^{21}$ Note that neither the bank nor the household are able to distinguish ex ante which banks will be unable to claim collateral. Only the proportion $\chi_{t}$ is known.

${ }^{22}$ Note that the remaining $\chi_{t}$ proportion of banks make a profit of $\int_{\underline{\varepsilon}}^{\varepsilon_{j, t}^{F, M}}\left[\left(1-\chi_{t}\right) Y_{j, t}\right] f\left(\varepsilon_{j, t}^{F}\right) d \varepsilon_{j, t}^{F}$ such that the aggregate gains from non-defaulting banks would offset exactly the losses outlined in equation (17). Banks are assumed not to be risk sharing with aggregate financial intermediation profits transferred back to households as a lump-sum at the end of the period. Significantly, all households receive a share of these profits regardless of whether or not they invest in bank capital. As a result, what matters for the households bank capital decision is the no-arbitrage condition capturing ex-ante banking sector losses, rather than the lump-sum transfer of profits.
} 


\subsubsection{Bank Capital Requirements and Countercyclical Regulation}

The representative bank is subject to minimum risk sensitive bank capital requirements imposed by the central bank and set according to the Basel accords. At the beginning of each period the bank must issue a certain amount of capital that covers a given percentage of its loans to IG firms. The bank capital requirement is set equal to a simple exponential function,

$$
\frac{V_{t}}{L_{t}} \equiv \Delta_{t}=\left(\Delta_{t-1}\right)^{\phi_{\Delta}}\left[\rho\left(\frac{\Phi_{t}}{\Phi}\right)^{\theta^{C}}\right]^{1-\phi_{\Delta}}
$$

with $\rho$ denoting the minimum capital adequacy requirements, also known as the Cooke Ratio (set by legislation). The term $\phi_{\Delta} \in(0,1)$ denotes a persistence parameter capturing the idea of policy makers altering required capital very smoothly. This is in part due to implementations lags, where banks may not be able to raise substantial amount of capital quickly, and because policy makers can be uncertain as to the macroeconomic impact of their actions. The term $\theta^{C}$ is an adjustment parameter that allows for dynamic bank capital requirements responding to deviations in cyclical risk. $^{23}$

Through equation (19), we can examine the differences between Basel I, Basel II and Basel III regulatory regimes. Specifically, $\theta^{C}=0$ reproduces the Basel I regime, in which the capital ratio is fixed and set to $\rho=0.08$. Values of $\theta^{C}>0$ mimic the minimum capital requirements under the foundation Internal Ratings Based (IRB) of Basel II, where the regulatory ratio increases with the perceived credit risk in the banks' loan portfolio. Negative values for $\theta^{C}<0$ would imply that bank capital requirements increase (decrease) in periods of low (high) credit risk. As the risk of default in our model is endogenously and negatively related to output and lending, imposing $\theta^{C}<0$ means that bank capital requirements should be loosened (tightened) during economic recessions (expansions). This type of countercyclical bank capital requirement rule is consistent with the proposed Basel III accords (see BCBS (2011, 2012)).

\subsubsection{The Transmission Channels of Risk and Bank Capital on the Loan Rate}

Applying the characteristics of the uniform distribution and the bank capital requirement (19), the lending rate equation (16) reduces to,

$$
R_{t}^{L}=\nu_{t}\left\{R_{t}^{D}+\left(\Delta_{t-1}\right)^{\phi_{\Delta}}\left[\rho\left(\frac{\Phi_{t}}{\Phi}\right)^{\theta^{C}}\right]^{1-\phi_{\Delta}}\left(R_{t}^{V}+c-R_{t}^{D}\right)\right\},
$$

\footnotetext{
${ }^{23}$ Our specification for bank capital requirements is similar to Angeloni and Faia (2013), who relate bank capital directly to deviations of output from its steady state level. Because risk in our model is endogenously and negatively linked to output and lending, responding directly to the business/financial cycle would produce similar policy implications. Some models, which abstract from an endogenous risk of default, use loans or the loan-output ratio to define a countercyclical regulatory rule. Angelini, Neri, and Panetta (2014), for example, emphasize the role of the loan-output ratio as an important indicator of financial risk. In practice, bank capital requirements should respond to systemic bank risk. However, the endogenous credit risk in our model is the source of the financial frictions. Thus, we employ a bank capital rule which targets the main variable that produces the financial accelerator effects and largely drives the movements in both real and financial variables through the borrowing cost channel. In the absence of a well-defined variable capturing systemic bank risk, the most suitable and important variable bank capital requirements can respond to in this setup is credit risk. In fact, Demirguc-Kunt and Detragiache (2005) find that bank failures are generally positively correlated with nonperforming loans - measured by credit risk in this model.
} 
where $\Phi_{t}$ is determined by (9) and (10), $R_{t}^{V}$ by (4) and (18), and $\nu_{t} \equiv\left[1-\frac{\left(\bar{\varepsilon}^{F}-\varepsilon^{F}\right)}{2 \varepsilon_{t}^{F, M}} \Phi_{t}^{2}\right]^{-1}>$ 1 is defined as the finance premium, which itself increases endogenously with the lending rate (from equations 9 and 10). As a clear analytical solution to the quadratic loan rate equation is unattainable, we resort later to numerical solutions which illuminate the channels explained in this section. ${ }^{24}$

Equation (20) shows that the loan rate is positively related to the deposit rate, the finance premium, the bank capital-deposit rate spread and the issuance cost of bank capital. The bank capital-deposit rate spread and the cost of issuing bank capital, in turn, are set as a proportion of the bank capital-loan ratio, which is determined by the Cooke Ratio $(\rho)$, and the cyclical adjustment parameter $\left(\theta^{C}\right)$ prevailing under Basel II or Basel III.

We identify various channels through which the probability of default impacts the loan rate. The first, defined as the bank capital default channel, stems from a combination of a positive level of default costs on bank capital and the no-arbitrage condition, relating the bank capital rate to the deposit rate and to the bank capital risk premium rate $\left(\xi_{t}^{V}\right)$. The risk premium on bank capital, in turn, relates positively to the risk of default at the IG firm level and negatively to the bank capital-loan ratio (see equations 4 and 18). Second, the finance premium channel, arising from the positive correlation between the risk of default and the finance premium, which directly influences the cost of credit. Third, under Basel II and Basel III, the probability of default affects the lending rate through the bank capital requirements channel, in which the sign of $\theta^{C}$ determines the direction of adjustment in bank capital.

The bank capital-loan ratio in our model has an ambiguous impact on the loan rate. On the one hand, tighter bank capital regulation increases the cost of credit through the direct positive relationship between $R_{t}^{L}$ and the positive spread $R_{t}^{V}+c-R_{t}^{D}$ (set as a fraction of $\Delta_{t}=V_{t} / L_{t}$ ). On the other hand, a rise in the bank capital-loan ratio reduces the risk premium on bank capital, thereby lowering the loan rate via the bank capital default channel (see equation 18). With higher bank capital requirements, there is a higher equity base to absorb commercial bank losses resulting in an attenuation effect on the bank capital premium rate, the bank capital-deposit rate spread and the cost of credit.

The decline in the bank capital risk premium brought about by the higher capital ratio is consistent with the logic of the Modigliani and Miller (1958) theorem and supported by a large body of empirical evidence (see Barth, Caprio and Levine (2004); Coleman, Esho and Sharpe (2006); and Kashyap, Stein and Hanson (2010)). Moreover, Admati and Hellwig (2014) argue that bank capital is inexpensive and lowers the risk premium on equity, leading also to fewer distortions in lending decisions and to better performing banks. In our model, the contradicting effects of bank capital regulation on the loan rate largely offset one another in steady state and minimize the role for time-varying regulation in the model dynamics. The effectiveness of dynamic capital requirements is restored when some small additional issuance costs of bank capital $(c)$ are added (see for example Covas and Fujita (2010) and Gerali, Neri, Sessa and Signoretti (2010)). ${ }^{25}$ This cost (resembling a tax advantage of debt over equity) puts the increase in the weighted average

\footnotetext{
${ }^{24}$ However, in the appendix we solve the loan rate equation in steady state using some simplifying assumptions, which helps to better understand the role of bank capital requirements.

${ }^{25}$ Through numerical methods we show that in order for the steady state loan rate to increase following a rise in bank capital requirements, $c \geq 0.0014$. In the simulations we use a larger value of $c$ to ensure a plausible steady state loan rate.
} 
cost of capital and the loan rate following a rise in bank capital into a reasonable empirical range (see also Hanson, Kashyap and Stein (2011)).

A key element in this setup is that the probability of default is a function of the loan rate, while the bank capital rate is a function of default risk and commercial bank losses (from the noarbitrage condition). Hence, an adverse shock, associated with falling levels of output (collateral), leads to increased financial risk, and accordingly results in a rise in the bank capital rate and regulatory requirements (in the benchmark Basel II case where $\theta^{C}>0$ ). The increase in bank capital costs then translate into a rise in the loan rate, thereby fuelling additional upward pressure on the risk of default and the bank capital premium rate, all of which ultimately amplify the initial increase in the lending rate. Therefore, the probability of default, through its relationship with regulatory requirements, the bank capital rate and the borrowing costs, aggravates the impact on the rest of the financial and economic variables. These frictions give rise to significant financial accelerator effects, supporting the general consensus in the literature regarding the procyclical nature of banking and more specifically of Basel II. The upshot is that macroprudential policy (Basel III, $\theta^{C}<0$ ) is warranted in order to insulate the effects of the borrowing cost channel and financial sector procyclicality on the real economy.

\subsection{Monetary Policy}

The central bank targets the short term policy rate $\left(R_{t}^{c b}\right)$ according to the following Taylor (1993)type policy rule, ${ }^{26}$

$$
R_{t}^{c b}=\left[\left(R^{c b}\right)\left(\frac{\pi_{t}^{P}}{\pi^{P, T}}\right)^{\phi_{\pi}}\left(\frac{Y_{t}}{Y}\right)^{\phi_{Y}}\left(\frac{R_{t}^{L} / R_{t}^{D}}{R^{L} / R^{D}}\right)^{-\phi_{s}}\right]^{1-\phi}\left(R_{t-1}^{c b}\right)^{\phi}
$$

where $\phi \in(0,1)$ is the degree of interest rate smoothing and $\phi_{\pi}, \phi_{Y}>0$ coefficients measuring the relative weights on inflation and output deviations from their steady state targets, respectively.

The new term added to the standard Taylor rule is given by $\left(\frac{R_{t}^{L} / R_{t}^{D}}{R^{L} / R^{D}}\right)^{-\phi_{s}}$, where $\phi_{s} \geq 0$. Thus, the central bank sets its policy rate also in part to deviations of credit spreads from their steady state level (see also Cúrdia and Woodford (2010)). ${ }^{27}$ In this way, following adverse shocks producing an output-inflation trade-off, the probability of default and loan rate increase, both of which reduce lending and increase credit spreads. With $\phi_{s}>0$, the policy rate falls and mitigates the initial increase in the lending rate, thereby dampening the contraction in credit and output, whilst mitigating the rise in inflation. However, an increase in the output gap followed by a lower policy rate may exert additional inflationary pressures through the standard demand channel of monetary policy.

\section{Equilibrium and Parameterization}

In line with the cost channel literature and for the goods market to clear, we assume the size of the liquidity injection plus the labour income subsidy (in real terms) is $X_{t}+\int_{0}^{1} \tau_{w} \frac{W_{i, t}}{P_{t}} H_{i, t} d i=$

\footnotetext{
${ }^{26}$ Using a no arbitrage condition and assuming no required reserves policies, the deposit rate is equal to the policy rate $\left(R_{t}^{D}=R_{t}^{c b}\right)$.

${ }^{27}$ Having the Taylor rule responding negatively to risk or positively to loans (or loan growth) in this model would not affect the results materially.
} 
$M_{t+1} \frac{P_{t+1}}{P_{t}}-M_{t}{ }^{28}$ Following the financial intermediation process, the central bank (acting also as the financial authority in the model) receives $R_{t}^{D} X_{t}+c V_{t}=J_{t}^{F I}$, which is rebated back to households as a lump-sum. ${ }^{29}$ In a symmetric equilibrium $\left(P_{j, t}=P_{t}, H_{j, t}=H_{t}, L_{j, t}=L_{t}\right)$, we substitute the IG firms profits, total profits from the financial intermediation process, the equilibrium condition in the market for loans $\left(W_{t}^{R} H_{t}=D_{t}+V_{t}+X_{t}\right)$, the no-arbitrage condition (4), and the size of the liquidity injection plus the labour income subsidy in identity (2) to obtain the market clearing condition, $Y_{t}=C_{t}$.

To solve the model, we log-linearize the behavioral equations and the resource constraints around the non-stochastic, zero inflation $\left(\pi^{P, T}=1\right)$ steady state and take the percentage deviation from their counterparts under flexible prices and wages. The model is calibrated, where applicable, within the range of the parameters proposed by Smets and Wouters (2003,2007) and Christiano, Eichenbaum and Evans (2005). ${ }^{30}$ The baseline parameterization values are summarized in the following Table 1,

Table 1: Benchmark Parameterization

\begin{tabular}{lll}
\hline \hline Parameter & Value & Description \\
\hline \hline$\beta$ & 0.99 & Discount Factor \\
$\varsigma$ & 1.00 & Intertemporal Substitution in Consumption \\
$\gamma$ & 2.00 & Inverse of the Frisch Elasticity of Labour Supply \\
$\lambda_{w}$ & 6.00 & Elasticity of Demand - Labour \\
$\omega_{w}$ & 0.64 & Degree of Wage Stickiness \\
$\lambda_{p}$ & 6.00 & Elasticity of Demand - Intermediate Goods \\
$\omega_{p}$ & 0.60 & Degree of Price Stickiness \\
$A$ & 1.00 & Average Productivity Parameter \\
$\bar{\varepsilon}^{F}$ & 1.36 & Idiosyncratic Productivity Shock Upper Range \\
$\underline{\varepsilon}^{F}$ & 1.00 & Idiosyncratic Productivity Shock Lower Range \\
$\chi$ & 0.97 & Probability of Banks Recovering Collateral \\
$\phi_{\Delta}$ & 0.00 & Degree of Persistence in Regulatory Rule \\
$\rho^{D}$ & 0.08 & Capital Adequacy Ratio \\
$\theta^{C}$ & 0.05 & Elasticity of Regulatory Rule wrt to Risk \\
$c$ & 0.25 & Administrative Cost of Issuing Bank Capital \\
$\phi^{F}$ & 0.70 & Degree of Persistence in Interest Rate Rule \\
$\phi_{\pi}$ & 2.00 & Response of Policy Rate to Inflation Deviations \\
$\phi_{Y}$ & 0.00 & Response of Policy Rate to Output Deviations \\
$\phi_{s}$ & 0.00 & Response of Policy Rate to Credit Spreads \\
$\varsigma^{A}$ & 0.91 & Degree of Persistence - Supply Shock \\
$\varsigma^{\chi}$ & 0.90 & Degree of Persistence - Credit Shock \\
\hline \hline
\end{tabular}

\footnotetext{
${ }^{28}$ Government is a veil in this model so for simplicity we assume that it is the central bank which subsidizes labour income and provides the liquidity injection. This liquidity injection and money carried over between periods, nonetheless, are introduced simply to clear the goods market, and have no meaningful effects in this model (see also Ravenna and Walsh (2006) and Erceg, Henderson and Levin (2000)).

${ }^{29}$ Recall that aggregate ex-post profits in the commercial banking sector are equal to zero.

${ }^{30}$ The results we present in the next sections are robust to changes in the standard parameters of the model such as the discount factor, wage and price rigidities (within plausible ranges), intertemporal substitution in consumption and the inverse of the Frisch elasticity of labour supply. We focus in this section on the parameters new to this model.
} 
Elaborating now on some parameters unique to this model; we set the idiosyncratic productivity shock's range to $(1,1.36)$, and the steady state probability of the bank recovering collateral $(\chi)$ to $97 \% .{ }^{31}$ Moreover, the bank capital adequacy ratio $(\rho)$ is set to 0.08 , which represents a floor value under Basel II. These numbers, together with a price mark-up of $20 \%$, generate a steady state credit risk of $3.82 \%$, a long run value of $2.48 \%$ for the return on bank capital and a loan rate of $3.15 \% .{ }^{32}$ All these estimates are consistent with values found for advanced economies. In our benchmark case before calculating optimal policy rules, we implement a Basel II regime $\left(\theta^{C}=0.05\right)$ and standard Taylor rule parameters $\left(\phi=0.7, \phi_{\pi}=2.0, \phi_{Y}=0\right.$ and $\left.\phi_{s}=0\right) .{ }^{33}$ The degree of persistence in the regulatory rule $\left(\phi_{\Delta}\right)$ is set to 0 , as we find that including this parameter increases welfare losses when the regulatory rule $\left(\theta^{C}\right)$ is set optimally. ${ }^{34}$

Finally, we calibrate the persistence parameters $\left(\varsigma^{i}\right)$ and standard deviations $\left(s . d\left(\alpha_{t}^{i}\right)\right)$ associated with financial $(i=\chi)$ and technology $(i=A)$ shocks to approximately match the standard deviations of loan rates, output and inflation in the U.S. data, over the period 2000:Q1-2015:Q2. The choice of the prior distributions are the same as those used in Christiano, Motto and Rostagno (2014). For financial shocks we obtain $\varsigma^{\chi}=0.90$ and $\operatorname{s.d}\left(\alpha_{t}^{\chi}\right)=0.124$, while for supply shocks the results imply $\varsigma^{A}=0.91$ and $\operatorname{s.d}\left(\alpha_{t}^{A}\right)=0.088 .^{35}$

\section{Optimal Simple Policy Rules and Welfare}

This section provides an analysis of the optimal mix of conventional and macroprudential policy instruments outlined above. The central bank's objective function is given by a second order approximation around the efficient steady state of the household's ex-ante expected utility written

\footnotetext{
${ }^{31}$ Reducing the steady state value of the probability $\chi$, which is a key financial friction in this model, raises the cost of borrowing in the long run as well as amplifies the response of both financial and real variables following various shocks.

${ }^{32}$ Indeed, the combination of values for $\chi, c, \rho$ and $\lambda_{p}$ are chosen so that the various steady state spreads and risk of default are consistent with the data.

${ }^{33}$ Under the foundation internal ratings based (IRB) approach of Basel II, the equivalent to $\theta^{C}$ lies between 0.05 and 0.10 (see Covas and Fujita (2010) and Aguiar and Drumond (2009)). Furthermore, a response to output $\left(\phi_{Y}\right)$ in the Taylor rule results in negligible welfare gains and is therefore ignored for the purpose of our optimal policy analysis (see also Schmitt-Grohé and Uribe (2007)). Abstracting from $\phi_{Y}$ also allows us to clearly establish and understand the interaction between the response to inflation in the standard Taylor rules and the new macroprudential instruments. Our baseline parameterization of $\phi$ and $\phi_{\pi}$ follows the benchmark case of Benes and Kumhof (2015).

${ }^{34}$ In other words, $\phi_{\Delta}$ is optimally set to 0 when searched along the $(0,1)$ grid.

${ }^{35}$ Our estimation results for the persistence and standard deviations of financial shocks are not inconsistent with Benes and Kumhof (2015), who also use additional shocks to calibrate their model. Evidently, our model is small scale and absent of habit persistence, physical capital, investment and additional various shocks (all of which are important to capture the quantitative volatilities as observed in the data). For future work, it would be interesting to build a larger scale model that could be taken to the data more easily, which would also enable us to calibrate the rest of the parameters of the model. Such a model would surely also feature a wider range of financial and real shocks. For the purpose of this paper, we perform a 'modest' estimation analysis in order to match some of the moments in the data.
} 
in 'gap' form, ${ }^{36}$

$$
\sum_{t=0}^{\infty} \beta^{t} U_{t} \approx U-\frac{1}{2} U_{C} C \mathbb{E}_{0} \sum_{t=0}^{\infty} \beta^{t}\left[\frac{\lambda_{p}}{k_{p}} \operatorname{var}\left(\widehat{\pi}_{t}^{P}\right)+\left(\varsigma^{-1}+\gamma\right) \operatorname{var}\left(\widehat{Y}_{t}^{g}\right)+\frac{\lambda_{w}}{k_{w}} \operatorname{var}\left(\widehat{\pi}_{t}^{W}\right)\right],
$$

where $k_{p}=\left(1-\omega_{p}\right)\left(1-\omega_{p} \beta\right) / \omega_{p}, k_{w}=\frac{\left(1-\omega_{w}\right)\left(1-\beta \omega_{w}\right)}{\omega_{w}\left(1+\gamma \lambda_{w}\right)}$ and $\widehat{Y}_{t}^{g}=\widehat{Y}_{t}-\widehat{Y}_{t}^{e}$ is the welfare relevant output gap. The term $\widehat{Y}_{t}^{e}=\left[(1+\gamma) /\left(\varsigma^{-1}+\gamma\right)\right] \widehat{Z}_{t}$ is the efficient level of output chosen by the social planner who can overcome all the nominal and financial frictions in this economy. Similar to Ravenna and Walsh (2006), the presence of the borrowing cost channel creates a wedge between the natural and efficient level of output; $\widehat{Y}_{t}^{e}-\widehat{Y}_{t}^{n}=\left[1 /\left(\varsigma^{-1}+\gamma\right)\right] \hat{R}_{t}^{L, n}$, where $\widehat{Y}_{t}^{n}$ and $\hat{R}_{t}^{L, n}$ denote the natural level (indexed by superscript $n$ ) of output and loan rate prevailing under flexible prices and wages. ${ }^{37}$

We study various optimal policy rules aimed at minimizing the loss function elements of the above welfare function. The policy rules examined are: Policy I (benchmark) - Basel II $\left(\theta^{C}=0.05\right)$ and a standard Taylor rule $\left(\phi_{\pi}=2.0\right.$ and $\left.\phi_{s}=0\right)$. Policy II - Basel II regime and the central bank responding optimally to inflation in the Taylor rule (solving for $\phi_{\pi}$, and setting exogenously $\theta^{C}=0.05$ and $\left.\phi_{s}=0\right)$. Policy III - Basel II and an optimal response to inflation and credit spreads (solving for $\phi_{\pi}$ and $\phi_{s}$, and setting $\theta^{C}=0.05$ ). Policy IV - an inflation targeting monetary policy rule and optimal bank capital regulation (solving for $\phi_{\pi}$ and $\theta^{C}$, and setting $\phi_{s}=0$ ). Policy $\mathrm{V}$ a credit spread-augmented Taylor rule and optimal macroprudential regulation (solving for $\phi_{\pi}, \theta^{C}$ and $\left.\phi_{s}\right)$. The optimal parameters that minimize the welfare loss function are grid-searched within the following ranges: $\phi_{\pi}=[1: 10], \phi_{s}=[0: 1]$ and $\theta^{C}=[-250: 1]$ with step of 0.01 .

We perform the comparison among the alternative policies in terms of a consumption equivalent $(\Lambda)$ given by the fraction of consumption required to equate welfare under benchmark Policy I, to the welfare associated with the various optimal policy rules (Policies II-IV). Such fraction $(\Lambda)$ is defined as $\mathbb{E}_{t} \sum_{t=0}^{\infty} \beta^{t} U_{t}\left(C_{t}^{j}, H_{t}^{j}\right)=\mathbb{E}_{t} \sum_{t=0}^{\infty} \beta^{t} U_{t}\left((1-\Lambda) C_{t}^{I}, H_{t}^{I}\right)$, where $j$ refers to Policies II-IV and superscript $I$ is Policy I. Given the specified utility function and with $\varsigma=1$, the expression for $\Lambda$ in percentage terms is,

$$
\Lambda=\left\{1-\exp \left[(1-\beta)\left(\mathbb{W}_{t}^{j}-\mathbb{W}_{t}^{I}\right)\right]\right\} \times 100
$$

with $\mathbb{W}_{t}^{j}=\mathbb{E}_{t} \sum_{t=0}^{\infty} \beta^{t} U_{t}\left(C_{t}^{j}, H_{t}^{j}\right)$ representing the unconditional expectation of lifetime utility under optimal policy rule $j$, and $\mathbb{W}_{t}^{I}=\mathbb{E}_{t} \sum_{t=0}^{\infty} \beta^{t} U_{t}\left(C_{t}^{I}, H_{t}^{I}\right)$ the welfare associated with the benchmark

\footnotetext{
${ }^{36}$ The derivation of the welfare loss function strictly follows Erceg, Henderson and Levine (2000) who introduce wage rigidities, and Ravenna and Walsh (2006) who incorporate the monetary policy cost channel. In the efficient steady state, wage and price markups are eliminated through appropriate subsidies. The detailed derivation of the loss function is available upon request.

${ }^{37}$ The richer borrowing cost channel therefore does not change the structure of the loss function compared to standard new Keynesian models with staggered wages. However, unlike Ravenna and Walsh $(2006)$, where $\hat{R}_{t}^{L, n}=0$, in our model the presence of the various financial frictions also lead to deviations in $\hat{R}_{t}^{L, n}$ and hence generate the wedge between $\widehat{Y}_{t}^{n}$ and $\widehat{Y}_{t}^{e}$ (see also Airaudo and Olivero (2014)).
} 
Policy I. A higher positive $\Lambda$ implies a larger welfare gain and hence indicates that the policy is more desirable from a welfare point of view. The steady state is independent of the monetary policy rule $\left(\phi_{\pi}, \phi_{s}\right)$ and the type of bank capital regulation $\left(\theta^{C}\right)$ so our computation of social welfare is comparable across all policy rules.

Table 2 shows the optimal simple policy rules, the standard deviations (measured in terms of the theoretical moments) of the variables comprising of the loss function, and the welfare gain in units of steady state consumption following a 1 standard deviation shock to $\chi_{t}$, and a 1 standard deviation shock to $A_{t} \cdot{ }^{38}$

Table 2: Optimal Simple Policy Rules and Standard Deviations

\begin{tabular}{|l|ll||ll|}
\hline \hline \multicolumn{3}{|c|}{ Credit Shock } & Supply Shock \\
\hline \hline Policy I & $\phi_{\pi}=2.00$ & $s . d\left(\widehat{\pi}_{t}^{P}\right)=0.0151$ & $\phi_{\pi}=2.00$ & $s . d\left(\widehat{\pi}_{t}^{P}\right)=0.0537$ \\
& $\phi_{s}=-$ & $s . d\left(\widehat{Y}_{t}^{g}\right)=0.0563$ & $\phi_{s}=-$ & $s . d\left(\widehat{Y}_{t}^{g}\right)=0.1109$ \\
& $\theta^{C}=0.05$ & $s . d\left(\widehat{\pi}_{t}^{W}\right)=0.0054$ & $\theta^{C}=0.05$ & $s . d\left(\widehat{\pi}_{t}^{W}\right)=0.0218$ \\
& & $\Lambda=-$ & & $\Lambda=-$ \\
\hline Policy II & $\phi_{\pi}=1.01$ & $s . d\left(\widehat{\pi}_{t}^{P}\right)=0.0152$ & $\phi_{\pi}=1.93$ & $s . d\left(\widehat{\pi}_{t}^{P}\right)=0.0539$ \\
& $\phi_{s}=-$ & $s . d\left(\widehat{Y}_{t}^{g}\right)=0.0301$ & $\phi_{s}=-$ & $s . d\left(\widehat{Y}_{t}^{g}\right)=0.1046$ \\
& $\theta^{C}=0.05$ & $s . d\left(\widehat{\pi}_{t}^{W}\right)=0.0051$ & $\theta^{C}=0.05$ & $s . d\left(\widehat{\pi}_{t}^{W}\right)=0.0220$ \\
& & $\Lambda=0.0829$ & & $\Lambda=0.0007$ \\
\hline Policy III & $\phi_{\pi}=1.01$ & $s . d\left(\widehat{\pi}_{t}^{P}\right)=0.0152$ & $\phi_{\pi}=1.93$ & $s . d\left(\widehat{\pi}_{t}^{P}\right)=0.0539$ \\
& $\phi_{s}=0.00$ & $s . d\left(\widehat{Y}_{t}^{g}\right)=0.0301$ & $\phi_{s}=0.00$ & $s . d\left(\widehat{Y}_{t}^{g}\right)=0.1046$ \\
& $\theta^{C}=0.05$ & $s . d\left(\widehat{\pi}_{t}^{W}\right)=0.0051$ & $\theta^{C}=0.05$ & $s . d\left(\widehat{\pi}_{t}^{W}\right)=0.0220$ \\
& & $\Lambda=0.0829$ & & $\Lambda=0.0007$ \\
\hline Policy IV & $\phi_{\pi}=A N Y$ & $s . d\left(\widehat{\pi}_{t}^{P}\right)=0.00$ & $\phi_{\pi}=9.30$ & $s . d\left(\widehat{\pi}_{t}^{P}\right)=0.0016$ \\
& $\phi_{s}=-$ & $s . d\left(\widehat{Y}_{t}^{g}\right)=0.00$ & $\phi_{s}=-$ & $s . d\left(\widehat{Y}_{t}^{g}\right)=0.0527$ \\
& $\theta^{C}=-0.11$ & $s . d\left(\widehat{\pi}_{t}^{W}\right)=0.00$ & $\theta^{C}=-196$ & $s . d\left(\widehat{\pi}_{t}^{W}\right)=0.0032$ \\
& & $\Lambda=0.2579$ & & $\Lambda=0.2684$ \\
\hline \hline \multirow{2}{*}{ Policy V } & $\phi_{\pi}=A N Y$ & $s . d\left(\widehat{\pi}_{t}^{P}\right)=0.00$ & $\phi_{\pi}=9.30$ & $s . d\left(\widehat{\pi}_{t}^{P}\right)=0.0016$ \\
& $\phi_{s}=A N Y$ & $s . d\left(\widehat{Y}_{t}^{g}\right)=0.00$ & $\phi_{s}=0.00$ & $s . d\left(\widehat{Y}_{t}^{g}\right)=0.0527$ \\
& $\theta^{C}=-0.11$ & $s . d\left(\widehat{\pi}_{t}^{W}\right)=0.00$ & $\theta^{C}=-196$ & $s . d\left(\widehat{\pi}_{t}^{W}\right)=0.0032$ \\
& & $\Lambda=0.2579$ & & $\Lambda=0.2684$ \\
\hline \hline
\end{tabular}

Note: $\Lambda$ is a measure of welfare gain in units of steady-state consumption

\subsection{Financial (Credit) Shock}

Figure 1 depicts the impulse response functions associated with the optimal policy parameters calculated in Table 2 following a 1 percent adverse financial shock.

\footnotetext{
${ }^{38}$ The value $\theta^{C}=0.05$ in Policies I,II,III is not optimized and is the benchmark regulatory regime (Basel II) in this model.
} 
Figure 1 - Adverse Financial Shock with Optimal Policy Rules
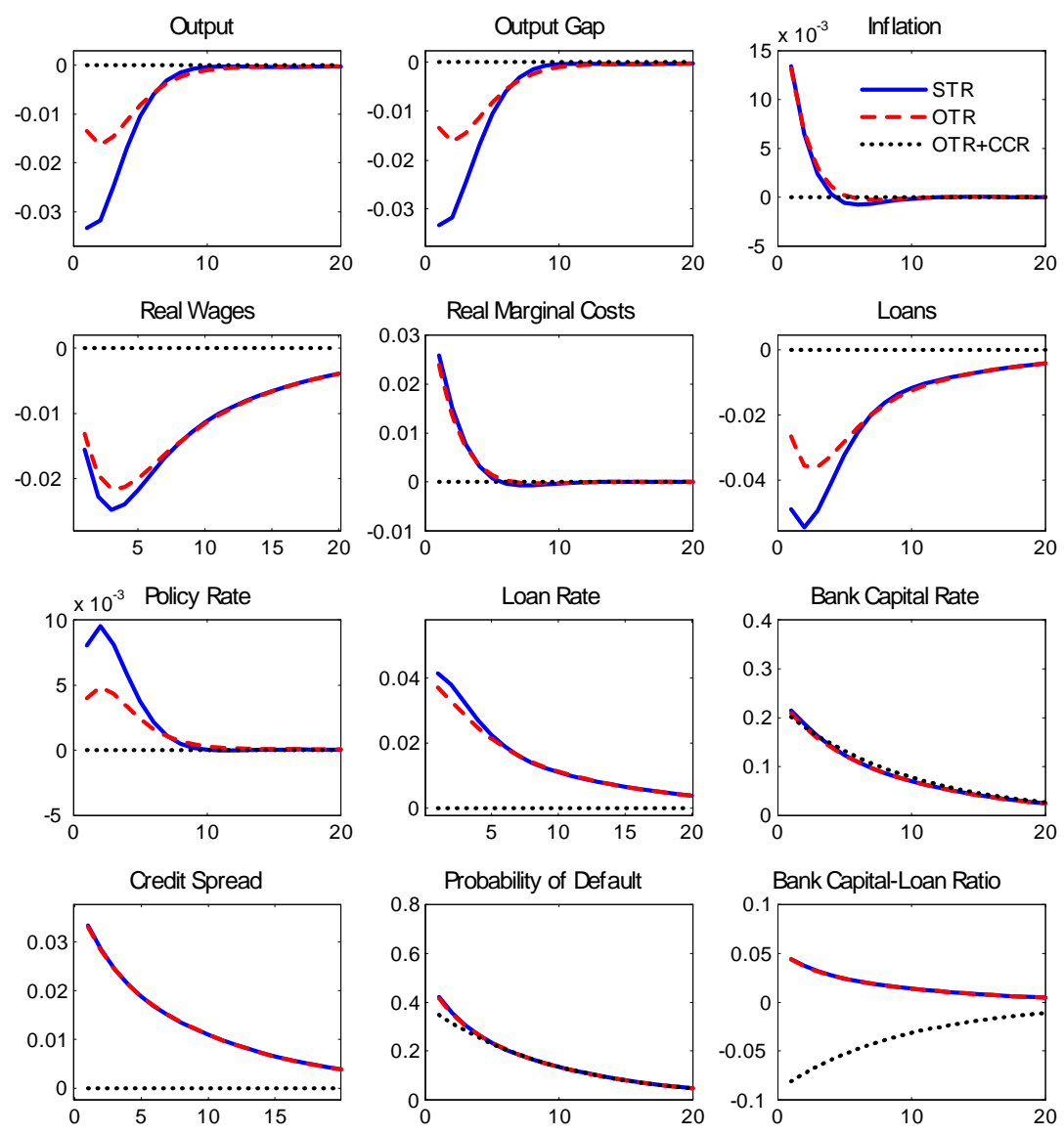

i) Figure 1 compares between Policy I (Standard Taylor Rule (STR)), Policy II (identical to Policy III - Optimal Taylor Rule (OTR)) and Policy IV (identical to Policy V - Optimal Taylor Rule + Countercyclical Rule (OTR+CCR)). ii) Interest rates, inflation rate, the probability of default and the bank capital-loan ratio are measured in percentage point deviations from steady state. The rest of the variables are measured in terms of percentage deviations.

In benchmark Policy I, a negative credit shock leads to a rise in the probability of default and consequently the loan rate through the bank capital default and finance premium channels. With a Basel II regime $\left(\theta^{C}=0.05>0\right)$, bank capital requirements increase, inducing an amplification effect on the borrowing costs and credit risk. It can be shown that both the bank capital default and the bank capital requirement channels lead to an exacerbation in the loan rate and risk of default behaviour compared to the Basel I case $\left(\theta^{C}=0\right)$ and to the scenario where banks are 
not subject to any capital regulation. ${ }^{39}$ The increase in the loan rate, coupled with the rise in risk, raises the marginal cost, increases price inflation and lowers output through the borrowing cost channel. Moreover, with standard Taylor rule parameters $\left(\phi_{\pi}=2.0\right)$, the policy rate rises in response to the increase in prices, thereby generating an additional upward shift in the bank capital and loan rates, and fuelling a further decline in both aggregate demand and lending. This result captures the trade-off between price inflation and output following financial shocks, consistent with the empirical findings of Gilchrist, Schoenle, Sim and Zakrajsek (2016) - see also the efficiency frontier (Taylor curve) below that highlights this result. The fall in real wages, as a result of lower output and higher price inflation, attenuates the rise in the marginal cost, but this moderation effect is relatively small given the nature of the financial shock hitting directly credit spreads.

A more moderated response to inflation in the Taylor rule (Policy II) provides non-negligible welfare gains compared to a standard monetary policy rule (Policy I). Intuitively, for economies where credit plays a key role for firms financing, responding too aggressively to price inflation may prompt higher borrowing costs and increased procyclicality in output, prices, wages and financial variables. By mitigating the rise in the policy rate, the inflationary impact of the borrowing cost channel is dampened, which leads to a relative improvement in output and wages. At the same time, the muted rise in the refinance rate can also exert higher inflationary pressures through the standard demand channel of monetary policy. Compared to Policy I, Policy II has a limited impact on price and wage inflation due to these conflicting channels. However, given the lower volatility in output, it is optimal to respond only minimally to inflation in the Taylor rule $\left(\phi_{\pi}=1.01\right)$.

In Policy III, we observe that a credit spread-augmented monetary policy rule does not promote overall welfare as it increases volatility in price and wage inflation, despite mitigating output losses. By calculating the theoretical moments, our experiments show that even just a small reaction to credit spreads $\left(\phi_{s}=0.01\right)$, when $\phi_{\pi}$ is set optimally at 1.01 , increases the standard deviation in price inflation from 0.0152 to 0.0162 , and in wage inflation from 0.0051 to 0.0062 , while reducing the standard deviation in output from 0.0301 to 0.0264 . Intuitively, lowering the policy rate due to higher credit spreads increases initially the level of output through an intertemporal substitution effect, and attenuates the rise in the loan rate through the monetary policy cost channel. However, the relative rise in output and therefore the output gap, brought about by the fall in the refinance rate, translates into an increase in price inflation through the standard demand channel of monetary policy. Given our standard parameterization, the latter channel dominates such that a fall in the policy rate is indeed inflationary. Importantly, note that fluctuations in financial variables (loans, credit spreads and default risk) display high levels of endogenous persistence compared to the aggregate macro variables (output and inflation). Thus, a reaction to a financial indicator in the Taylor rule implies a more prolonged relative expansion in aggregate demand, which, in turn, leads to a sustained rise in price and wage inflation via the monetary policy demand channel. This outcome highlights why monetary policy leaning against financial instability (as measured by credit spreads and risk of default in this model) may be welfare detrimental, especially with a relatively stronger weight attached to price and wage inflation variances compared to the output gap volatility in the micro-founded welfare function.

An optimal Basel III type countercyclical regulatory policy $\left(\theta^{C}=-0.11\right)$ provides the most targeted approach as it directly suppresses the inflationary effect of credit spreads and the borrowing cost channel as well as shuts down all output and wage inflation fluctuations (see Policies IV

\footnotetext{
${ }^{39}$ These simulations are available upon request.
} 
and V). ${ }^{40}$ Put differently, following credit shocks, an optimal well-designed macroprudential rule eliminates the standard output-price inflation-wage inflation trade-off faced by the central bank and improves welfare by 0.2579 percent of permanent consumption compared to the benchmark policy. This welfare gain followed by an implementation of a financial macroprudential tool is large by the standards of the literature (see Unsal (2013) and Angeloni and Faia (2013), for example), but reinforces the significant welfare improvement found in the estimated model of Benes and Kumhof (2015). ${ }^{41}$ In fact, during an adverse credit cycle, a simple implementable macroprudential policy rule associated with a fall of around 0.08 percentage points in bank capital requirements (well within the bank capital buffer range of 0 to 2.5 percentage point deviation as proposed by Basel III) achieves fully optimal policy corresponding with zero welfare losses. ${ }^{42}$ Moreover, once the countercyclical rule is set optimally, the extent to which the monetary policy rule reacts to inflation and/or to credit spreads is irrelevant since all gaps are closed and the policy rate remains unchanged. ${ }^{43}$ An overreaction in the countercyclical rule can generate excessive easing in bank capital requirements, that overly reduce total bank funding costs and create a credit-fuelled economic boom inherent in increased welfare losses. Figure 2 illustrates the effectiveness of macroprudential regulation, the welfare detrimental aspects of a strict inflation targeting rule, and the point at which welfare losses (measured in absolute value) are minimized, and monetary policy rules become futile.

\footnotetext{
${ }^{40}$ The easing of bank capital requirements implied by the optimal macroprudential rule offsets the rise in the loan rate following the adverse financial shock. At the same time, lower bank capital requirements can also increase the cost of borrowing via the bank capital default channel as explained earlier. Given our parameterization with a small positive $c$, the direct positive relationship between bank capital requirements and the lending rate dominates the negative link between the bank capital-loan ratio and the bank capital premium rate, which positively impacts the loan rate. The focus is therefore on the positive interaction between bank capital requirements and the borrowing costs, which is also more consistent with empirical studies.

${ }^{41}$ In Unsal (2013), the welfare gain from broad macroprudential policies comes mainly from optimal monetary policy rules reacting also against financial imbalances rather than from a financial regulatory instrument. Conversely, following empirically-relevant bank riskiness shocks, Benes and Kumhof (2015) find that a countercyclical capital buffer leads to significant welfare benefits, and also reduces the role for credit-augmented monetary policy rules. Our policy results are therefore more in line with the latter paper.

${ }^{42}$ Bianchi (2011) finds that a simple macroprudential policy in the form of fixed tax on debt can nearly replicate a fully optimal policy.

${ }^{43}$ The only restriction is that $\phi_{\pi}$ must be greater than 1 to ensure determinacy.
} 
Figure 2 - Relationship Between $\phi_{\pi}, \theta^{C}$ - Credit Shocks

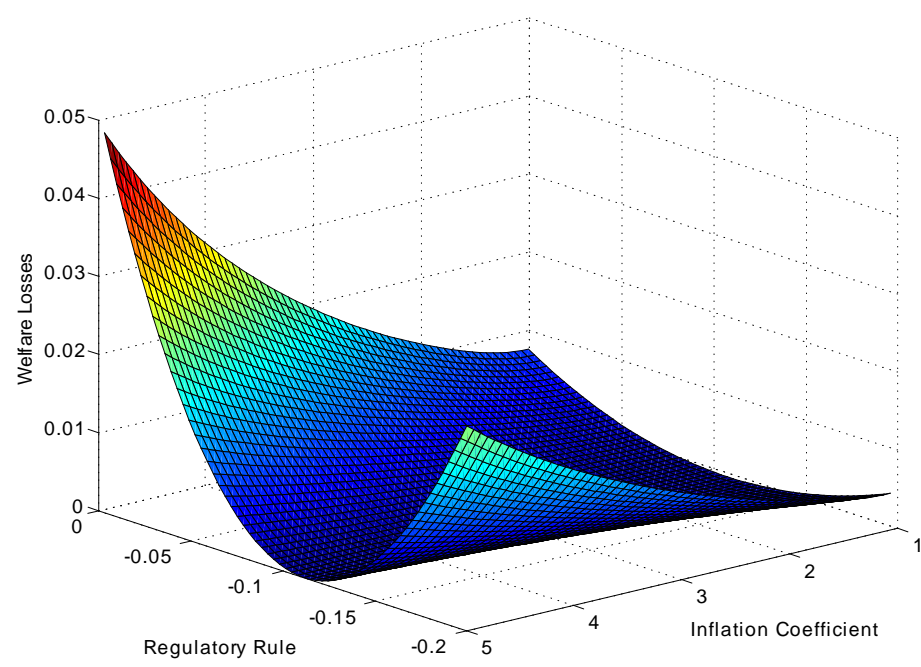

The results above show that macroprudential regulation in the form of countercyclical capital regulation can achieve the primary mandates of the central bank and deliver zero welfare losses following financial shocks. To further illustrate how countercyclical regulation responding to credit risk can minimize the trade-offs between output variability, price inflation variability and wage inflation variability, we construct an efficiency frontier (Taylor curve) that includes these three objectives of the policy maker (as implied by our micro-founded welfare loss function). ${ }^{44}$ For this purpose, we plot the Taylor curves with and without macroprudential policy.

Figure 3 presents our three-dimensional policy frontier under Basel II and Basel III. As clearly illustrated under the Basel II $\left(\theta^{C}>0\right)$ benchmark case, there is a clear trade-off between the three bank objectives following a 1 percent financial shock (in line with Gilchrist, Schoenle, Sim and Zakrajsek (2016)). Under Basel III $\left(\theta^{C}<0\right)$, nonetheless, this trade-off is considerably alleviated as there is lower volatility in output, price inflation and wage inflation. Compared to Rubio and Carrasco-Gallego (2014), our results suggest that macroprudential regulation, even on its own, can produce a more stable economic system, while monetary policy, under financial shocks, plays only a minimal role. ${ }^{45}$

\footnotetext{
${ }^{44}$ See also Rubio and Carrasco-Gallego (2014) who evaluate the performance of a Taylor rule in minimizing variability in output, inflation and borrowing.

${ }^{45}$ Including a measure of financial stability, such as credit spreads, loans or loan to GDP, would not change our results given the interconnection between the financial sector and the real economy in this model.
} 
Figure 3 - Three-Dimensional Efficiency Frontier

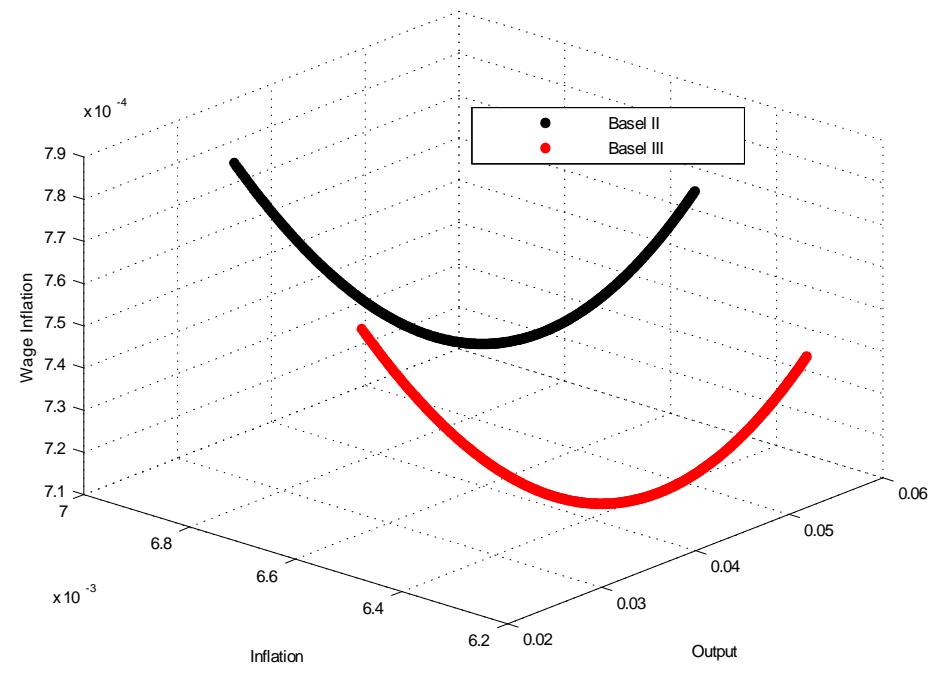

\subsection{Supply Shock}

Figure 4 shows the impulse response functions associated with the optimal policy parameters obtained in Table 2 for an adverse 1 percent supply shock. 
Figure 4 - Negative Supply Shock with Optimal Policy Rules
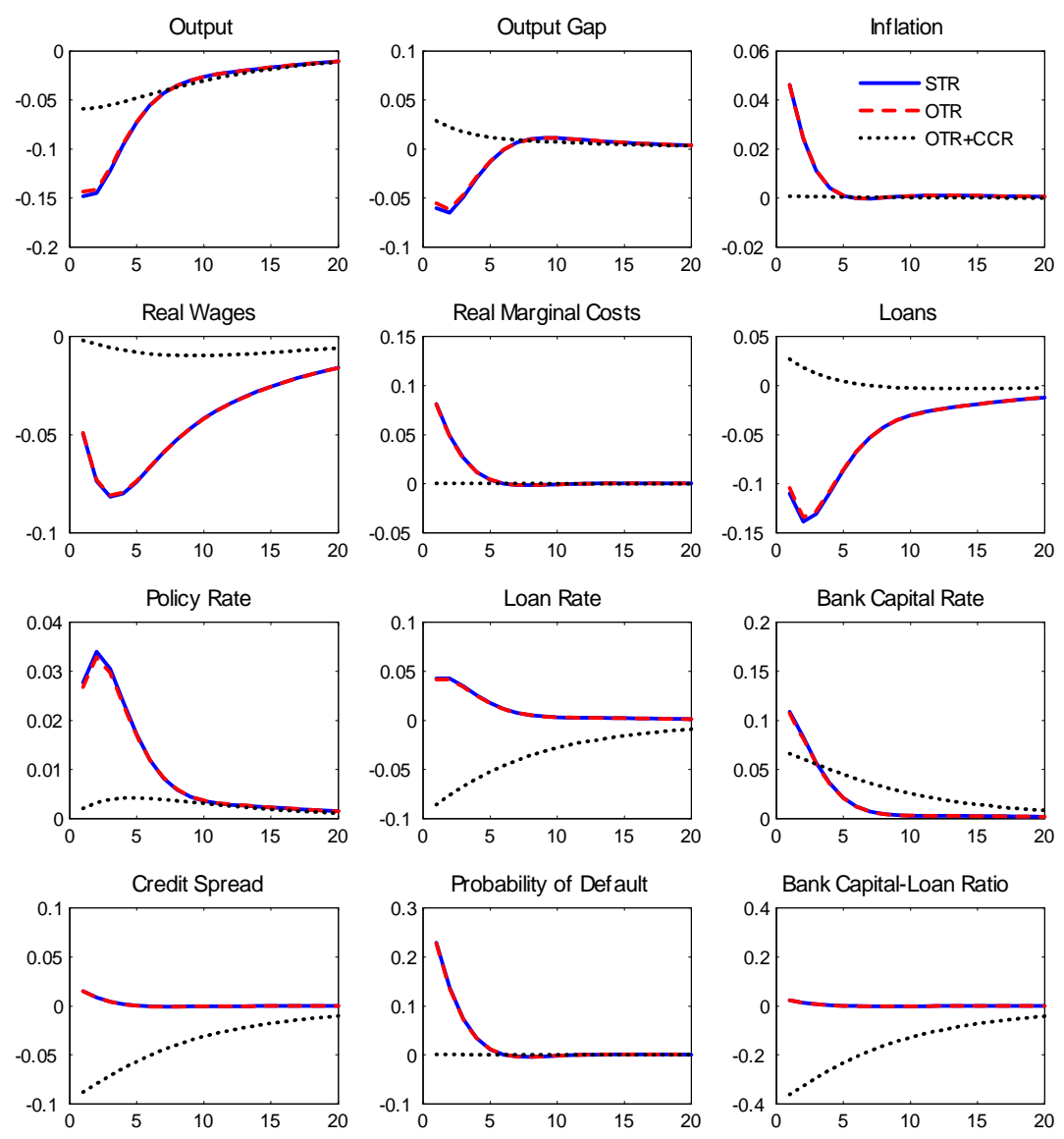

i) Figure 4 compares between Policy I (Standard Taylor Rule (STR)), Policy II (identical to Policy III - Optimal Taylor Rule (OTR)) and Policy IV (identical to Policy V - Optimal Taylor Rule + Countercyclical Rule (OTR+CCR)). ii) Interest rates, inflation rate, the probability of default and the bank capital-loan ratio are measured in percentage point deviations from steady state. The rest of the variables are measured in terms of percentage deviations.

In benchmark Policy I, a negative supply shock directly lowers the level of GDP and raises price inflation via the NKPC equation. As output falls, collateral declines as well, which, through the finance premium channel, increases both the probability of default and the loan rate. The bank capital default and Basel II $\left(\theta^{C}=0.05>0\right)$ channels behave similarly to adverse credit shocks and result in a further amplification in the reaction of the loan rate and risk of default. Note also that the output gap rises as this variable is measured in terms of the deviations of output from its efficient level $\left(\widehat{Y}_{t}^{g}=\widehat{Y}_{t}-\widehat{Y}_{t}^{e}\right.$, where $\left.\widehat{Y}_{t}^{e}=\left[(1+\gamma) /\left(\varsigma^{-1}+\gamma\right)\right] \widehat{Z}_{t}\right)$. Beyond the direct impact of the productivity shock, the higher loan rate aggravates the response of price inflation 
and lowers real wages, which, in turn, has an attenuating effect on the probability of default and the lending rate. Compared to adverse financial shocks, the drop in real wages is relatively stronger following technology shocks, thereby reducing the impact of the borrowing cost channel. However, given the nature of the supply shock and the various financial accelerator mechanisms led by bank capital requirements under Basel II, the loan rate and credit spreads increase, output falls, inflation rises and loans decrease. Finally, the policy rate rises in response to the hike in inflation, thereby stimulating a further decline in output.

In Policy II, optimal monetary policy suggests a slightly lower response to inflation in the Taylor rule as it mitigates the fall in the output gap. Excessively high inflation coefficient weights are avoided as they would lead to an intensified rise in inflation, thereby fuelling additional volatility in this variable. The slightly lower weight on inflation $\left(\phi_{\pi}=1.93\right)$ mitigates the inflationary impact of the monetary policy cost channel, although this rise in inflation is largely offset by the fall in the output gap (the standard demand channel of monetary policy). Furthermore, financially-augmented monetary policy rules add zero welfare gains as they act to increase output gap inefficiencies, leading to higher variances in price and wage inflation (Policy III).

Similar to credit shocks, countercyclical bank capital regulation has an important role in reducing welfare losses. Nevertheless, and unlike credit shocks, an optimal very aggressive countercyclical regulatory rule $\left(\theta^{C}=-196\right)$ is also welfare improving. Intuitively, deviations in price inflation, output and wage inflation stem mainly from the direct effect of the productivity shock rather than the secondary impact resulting from the loan rate behaviour. Credit shocks, nonetheless, impact wages and inflation through their effect on the lending rate, which then feeds into the rest of the economy via the borrowing cost channel. In other words, the strength of the borrowing cost channel following technology shocks is relatively weaker compared to financial shocks. This implies that a much stronger countercyclical bank capital rule is needed in order to promote macroeconomic stability and welfare following supply shocks. Easing bank capital requirements by roughly 0.4 percentage points, again within the bank capital buffer range advocated by the Basel committee, reduces bank funding costs to the extent that it generates a fall in credit spreads. This helps to further offset some of the increase in the marginal cost and price inflation, although does not eliminate completely the standard effects of the supply shock and specifically the output gap-inflation trade-off.

In Policy IV we also observe a complementarity effect between the use of the countercyclical rule and the response to inflation in the Taylor rule. Increasing (in absolute value) the weight on the countercyclical rule reduces the cost of credit, thereby creating dis-inflationary pressures. This prompts the central bank to weigh inflation more heavily $\left(\phi_{\pi}=9.30\right)$ in order to effectively adjust the real interest rate in the Euler Equation and to avoid a further escalation in the output gap. Overly high inflation coefficients $\left(\phi_{\pi}>9.30\right)$ are avoided as they suppress the relative rise in output, which would exaggerate losses associated with wage inflation in the central bank's objective function. ${ }^{46}$ Finally, with an optimal macroprudential rule and consequently a higher optimal response to inflation in the monetary policy rule, there is no welfare gain from the central bank leaning against the credit cycle (Policy V).

Figure 5 illustrates this complementarity between the weight on inflation and the countercyclical rule. Macroprudential regulation can restore the strong anti-inflation stance in the Taylor rule, and the combination of both these rules yields the lowest welfare losses (measured in absolute value). ${ }^{47}$

\footnotetext{
${ }^{46}$ Indeed, if the central bank's objective function consisted only of inflation and output gap volatilities, the optimal weights on $\phi_{\pi}$ and $\theta^{C}$, when determined jointly, tend towards $\infty$ and $-\infty$, respectively.
} 
Figure 5 - Relationship Between $\phi_{\pi}, \theta^{C}$ - Supply Shocks

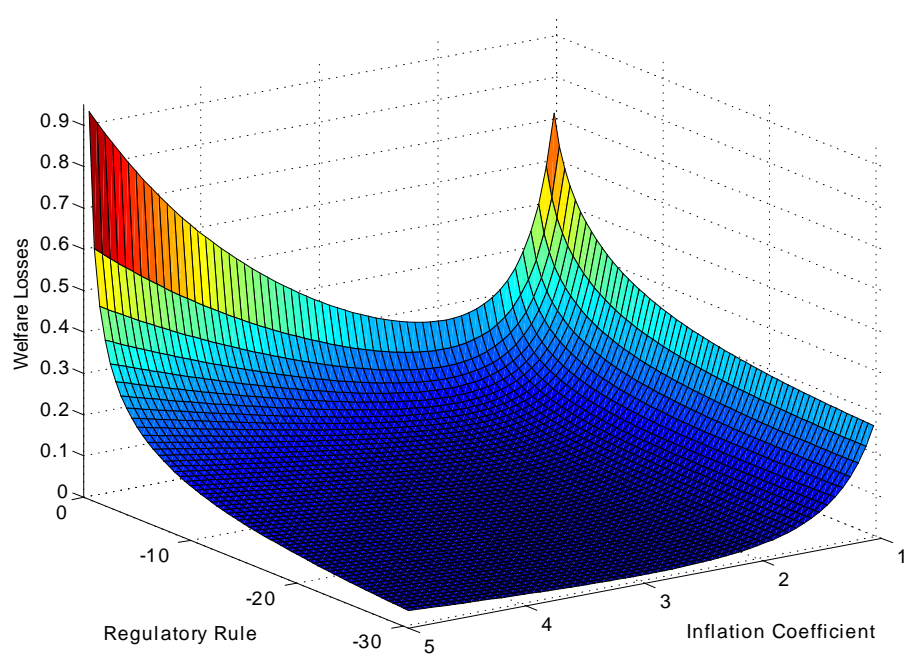

The general conclusion drawn from these experiments is that Basel III type rules, which directly impact the financial market conditions and the real economy via the borrowing cost channel, can effectively promote price stability and improve overall welfare for both credit and supply shocks (although to a different extent). ${ }^{48}$ Interestingly, following credit shocks, macroprudential regulation minimizes the trade-off between output and inflation stabilization, or even between macro stability and financial stability when the financial markets and real economy are intertwined. Credit spreadaugmented Taylor rules, on the other hand, are shown to be welfare detrimental, regardless if used in conjunction with a countercyclical regulatory rule, and irrespective of the type of shock hitting the economy. ${ }^{49,50}$ This final policy implication supports the 'conventional' wisdom (Bernanke and Gertler (2001)) and provides an alternative explanation to why monetary policy should not account for financial stability objectives in the Taylor rule; at least in a model where the borrowing cost channel creates endogenous persistence in financial variables, as well as a meaningful trade-off between output and inflation.

\footnotetext{
${ }^{47}$ In Figure 5, we limit the ranges of $\phi_{\pi}$ and $\theta^{C}$ to $(1,5)$ and $(-30,0)$ respectively. This enables us to illustrate the complementarity between these two policy rules in a transparent way, without compromising our main conclusions.

${ }^{48}$ As opposed to Angelini, Neri and Panetta (2014), we find that countercyclical regulation is not only effective following financial shocks but also in response to more standard supply shocks. Furthermore, with the financial regulator in this model being the central bank, and with a micro-founded welfare loss function, the coordination problems between the two authorities (who may have different loss functions) are absent. In fact, in our model, monetary policy and Basel III regulation are complementary to one another following supply shocks.

${ }^{49}$ We have also confirmed this result following policy (demand) shocks, which, similarly to financial and supply shocks, move output and inflation in opposite directions. Under these shocks, an unexpected rise in the policy rate leads to a fall in output (through an intertemporal substitution effect) and to a rise in inflation (via the monetary policy cost channel), thereby giving rise to the 'price puzzle' effect observed in many empirical studies.

${ }^{50}$ Gelain, Lansing and Mendicino (2013) find that financially-augmented Taylor rules reduce volatility of key variables at the cost of increasing inflation volatility. We support this initial result and further conclude that financially modified monetary policy rules provide zero welfare benefits.
} 


\section{Conclusion}

We develop an important framework for identifying the interactions between the credit markets and the real business cycle, as well as evaluating the macroprudential roles of bank capital regulation and monetary policy in promoting financial and macroeconomic stability. Key features of this DSGE setup include nominal rigidities, endogenous credit frictions and a borrowing cost channel.

The policy lessons arising from our model imply that central banks should reduce their inflation response in the Taylor rule in spite of higher inflationary pressures, and in the presence of a borrowing cost channel driven mainly by financial frictions. However, following standard supply shocks, introducing countercyclical regulation, as proposed by Basel III, allows central banks to be more stringent on inflation and control for price volatility via the standard demand channel of monetary policy. For these shocks, an aggressive countercyclical regulatory response to credit risk enables the policy maker to counter (but not eliminate) the standard effects of supply shocks. For credit shocks directly affecting default risk and credit spreads, Basel III type rules can eliminate macroeconomic gaps, the output-price inflation-wage inflation trade-off, and therefore the need for conventional monetary policy rules. In this framework, the adverse procyclical spillover consequences of the financial shock are completely offset by an appropriate countercyclical response to credit risk, which effectively restores the equilibrium price of credit. These state contingent results indicate the importance of identifying the source of economic disturbances for the design of macroprudential regulation and monetary policy (in line with Kannan, Rabanal and Scott (2012)). Finally, this paper captures the behavioral dynamics of financial and real variables following economic and financial disturbances, as well as provides meaningful and non-trivial policy implications when the borrowing cost channel and financial frictions matter.

A key practical issue in the context of our paper and more generally in the macroprudential literature is how macroprudential policies can be implemented without adversely affecting the credibility of central banks and regulatory authorities? The common tradition in central banks is to target inflation in an aggressive manner, but if financial regulation can perform better in terms of achieving price stability, how would this impact the anti-inflation credibility of central banks? Hence, these macroprudential tools must be calibrated jointly with a transparent communication of the specific roles of central banks and the regulatory authorities, which in essence may achieve the primary objectives of traditional monetary policy in periods of financial distress. 


\section{References}

[1] Admati, Anat, and Martin Hellwig. (2014). "The Bankers' New Clothes: What's Wrong with Banking and What to Do about It", Princeton, NJ: Princeton University Press.

[2] Agénor, Pierre-Richard, and Joshua Aizenman. (1998). "Contagion and Volatility with Imperfect Credit Markets", IMF Staff Papers, 45, 207-235.

[3] Agénor, Pierre-Richard, George J. Bratsiotis, and Damjan Pfajfar. (2014). "Credit Frictions, Collateral and the Cyclical Behaviour of the Finance Premium", Macroeconomic Dynamics, 18, 985-997.

[4] Agénor, Pierre-Richard, and Luiz A. Pereira da Silva. (2014). "Macroprudential Regulation and the Monetary Transmission Mechanism." Journal of Financial Stability, 13, 44-63.

[5] Aguiar, Alvaro, and Ines Drumond. (2009). "Business Cycle and Bank Capital: Monetary Policy Transmission under the Basel Accords", FEP Working paper No. 242, University of Porto.

[6] Airaudo, Marco, and María P. Olivero. (2014). "Optimal Monetary Policy with CounterCyclical Credit Spreads", Working Paper No. 2014-1, LeBow College of Business, Drexel University.

[7] Angelini, Paolo, Stefano Neri, and Fabio Panetta. (2014). "The Interaction between Capital Requirements and Monetary Policy", Journal of Money, Credit and Banking, 46(6), 1074-1112.

[8] Angeloni, Ignazio, and Ester Faia. (2013). "Capital Regulation and Monetary Policy with Fragile Banks", Journal of Monetary Economics, 60, 311-324.

[9] Barth, James R., Gerard Caprio Jr., and Ross Levine. (2004). "Bank Regulation and Supervision: What Works Best", Journal of Financial Intermediation, 12, 205-248.

[10] Basel Committee on Banking Supervision. (2011). "Basel III: A Global Regulatory Framework for more Resilient Banks and Banking Systems", Report No. 189.

[11] Basel Committee on Banking Supervision. (2012). "Models and Tools for Macroprudential Analysis", Working Paper No. 21, Bank for International Settlements.

[12] Benes, Jaromir, and Michael Kumhof. (2015). "Risky Bank Lending and Countercyclical Capital Buffers", Journal of Economic Dynamics and Control, 58, 58-80.

[13] Bernanke, Ben S., Mark Gertler, and Simon Gilchrist. (1999). "The Financial Accelerator in a Quantitative Business Cycle Framework", In John B. Taylor and Michael Woodford (Eds), Handbook of Macroeconomics, Vol. 1C, 1341-1393, Amsterdam, North Holland (Elsevier).

[14] Bernanke, Ben S., and Mark Gertler. (2001). "Should central banks respond to movements in asset prices?." The American Economic Review, 91(2), 253-257.

[15] Bianchi, Javier. (2011). "Overborrowing and Systemic Externalities in the Business Cycle", American Economic Review 101(7), 3400-3426. 
[16] Calvo, Guillermo A. (1983). "Staggered Prices in a Utility-Maximizing Framework", Journal of Monetary Economics, 12, 383-398.

[17] Christiano, Lawrence J., Martin Eichenbaum, and Charles L. Evans. (2005). "Nominal Rigidities and the Dynamic Effects of a Shock to Monetary Policy", Journal of Political Economy, $113,1-45$.

[18] Christiano, Lawrence J., Roberto Motto and, Massimo Rostagno. (2014). "Risk Shocks", American Economic Review, 104(1), 27-65.

[19] Christiano, Lawrence J., Martin S. Eichenbaum, and Mathias Trabandt. (2015). "Understanding the Great Recession", American Economic Journal: Macroeconomics, 7(1), 110-167.

[20] Clerc, Laurent, Alexis Derviz, Caterina Mendicino, Stephane Moyen, Kalin Nikolov, Livio Stracca, Javier Suarez, and Alexandros Vardoulakis. (2015). "Capital Regulation in a Macroeconomic Model with Three Layers of Default", International Journal of Central Banking, 11(3), 9-63.

[21] Coleman, Anthony D.F., Neil Esho and Ian G. Sharpe. (2006). "Does Bank Monitoring Influence Loan Contract Terms?", Journal of Financial Services Research, 30(2), 177-198.

[22] Covas, Francisco, and Shigeru Fujita .(2010). "Procyclicality of Capital Requirements in a General Equilibrium Model of Liquidity Dependence", International Journal of Central Banking, $6(4), 137-173$.

[23] Cúrdia, Vasco, and Michael Woodford. (2010). "Credit Spreads and Monetary Policy", Journal of Money, Credit and Banking, 42 (s1), 3-35.

[24] De Fiore, Fiorella., and Oreste Tristani. (2013). "Optimal Monetary Policy in a Model of the Credit Channel", The Economic Journal, 123(571), 906-931.

[25] De Paoli, Bianca, and Matthias Paustian. (2013). "Coordinating Monetary and Macroprudential Policies", Staff Report No. 653, Federal Reserve Bank of New York.

[26] Debortoli, Davide., Jinill Kim, Jesper Lindé, and Ricardo Cavaco Nunes. (2015). "Designing A Simple Loss Function for the Fed: Does the Dual Mandate Make Sense?", Unpublished Manuscript.

[27] Demirgüç-Kunt, Asli, and Enrica Detragiache. (2005). "Cross-country empirical studies of systemic bank distress: a survey." National Institute Economic Review ,192(1), 68-83.

[28] Dixit, Avinash K., and Joseph E. Stiglitz. (1977). "Monopolistic Competition and Optimum Product Diversity", American Economic Review, 67, 297-308.

[29] Erceg, Christopher J., Dale W. Henderson, and Andrew T. Levin. (2000). "Optimal Monetary Policy with Staggered Wage and Price Contracts", Journal of Monetary Economics, 46, 281313.

[30] Faia, Ester, and Tommaso Monacelli. (2007). "Optimal Interest Rate Rules, Asset Prices, and Credit Frictions", Journal of Economic Dynamics and Control, 31(10), 3228-3254. 
[31] Fernandez-Corugedo, Emilio, Michael F. McMahon, Stephen Millard, and Lukasz Rachel. (2011). "Understanding the Macroeconomic Effects of Working Capital in the United Kingdom", Bank of England Working Paper No. 422, Bank of England.

[32] Gelain, Paolo, Kevin J. Lansing, and Caterina Mendicino. (2013). "House Prices, Credit Growth, and Excess Volatility: Implications for Monetary and Macroprudential Policy", International Journal of Central Banking, 9(2), 219-276.

[33] Gerali, Andrea, Stefano Neri, Luca Sessa, and Federico M. Signoretti. (2010). "Credit and Banking in a DSGE model of the Euro Area", Journal of Money, Credit and Banking, 42(s1), 107-141.

[34] Gilchrist, Simon, Raphael Schoenle, Jae Sim, and Egon Zakrajsek. (2016). "Inflation Dynamics During the Financial Crisis", Finance and Economics Discussion Series 2015-012. Washington: Board of Governors of the Federal Reserve System.

[35] Hanson, Samuel G., Anil K. Kashyap, and Jeremy C. Stein. (2011). "A Macroprudential Approach to Financial Regulation", The Journal of Economic Perspectives, 25(1), 3-28.

[36] Jermann, Urban, and Vincenzo Quadrini. (2012). "Macroeconomic Effects of Financial Shocks", American Economic Review, 102(1), 238-271.

[37] Kannan, Prakash, Pau Rabanal, and Alasdair M. Scott. (2012). "Monetary and Macroprudential Policy Rules in a Model with House Price Booms", The B.E. Journal of Macroeconomics, 12(1), Article 16.

[38] Kashyap, Anil K., Jeremy. C. Stein, and Samuel Hanson. (2010). "An Analysis of the Impact of Substantially Heightened' Capital Requirements on Large Financial Institutions", Unpublished Manuscript, University of Chicago.

[39] Liu, Guangling Dave, and Nkhahle E. Seeiso. (2012). "Basel II Procyclicality: The Case of South Africa", Economic Modelling, 29(3), 848-857.

[40] Markovic, Bojan. (2006). "Bank Capital Channels in the Monetary Transmission Mechanism", Bank of England Working Paper No. 313.

[41] Meh, Césaire A., and Kevin Moran. (2010). "The Role of Bank Capital in the Propagation of Shocks", Journal of Economic Dynamics and Control, 34(3), 555-576.

[42] Modigliani, Franco, and Merton H. Miller. (1958). "The Cost of Capital, Corporation Finance and the Theory of Investment", American Economic Review, 48(3), 261-297.

[43] N'Diaye, Papa. (2009). "Countercyclical Macroprudential Policies in a Supporting Role to Monetary Policy", IMF Working Paper No. 257, International Monetary Fund.

[44] Nolan, Charles, and Christoph Thoenissen. (2009). "Financial Shocks and the US Business Cycle", Journal of Monetary Economics, 56(4), 596-604.

[45] Ravenna, Federico, and Carl E. Walsh. (2006). "Optimal Monetary Policy with the Cost Channel", Journal of Monetary Economics, 53, 199-216. 
[46] Rubio, Margarita, and José A. Carrasco-Gallego. (2014). "Macroprudential and Monetary Policies: Implications for Financial Stability and Welfare", Journal of Banking and Finance, 49, 326-336.

[47] Rubio, Margarita, and José A. Carrasco-Gallego. (2016). "The New Financial Regulation in Basel III: A Macroprudential Approach", Journal of Financial Stability, forthcoming:

[48] Schmitt-Grohé, Stephanie, and Martın Uribe. (2007). "Optimal Simple and implementable Monetary and Fiscal Rules", Journal of Monetary Economics, 54(6), 1702-1725.

[49] Smets, Frank, and Raf Wouters. (2003). "An Estimated Stochastic General Equilibrium Model of the Euro area", Journal of the European Economic Association, 1(5), 1123-1175.

[50] Smets, Frank, and Raf Wouters. (2007). "Shocks and Frictions in US Business Cycles: A Bayesian DSGE Approach", American Economic Review, 97(3), 586-606.

[51] Suh, Hyunduk. (2014). "Dichotomy between Macroprudential Policy and Monetary Policy on Credit and Inflation", Economics Letters, 122(2), 144-149.

[52] Taylor, John B. (1993). "Discretion versus Policy Rules in Practice", Carnegie-Rochester Conference Series on Public Policy, 39, 195-214.

[53] Unsal, D. Filiz. (2013). "Capital Flows and Financial Stability: Monetary Policy and Macroprudential Responses", International Journal of Central Banking, 9(1), 233-285. 


\section{Appendix}

\subsection{The Simplified Loan Rate Equation in Steady State}

To provide an analytical solution for the loan rate equation in steady state, we make two simplifying assumptions: (a) A constant unit labour cost $W / A$, set equal to unity for convenience; (b) An idiosyncratic IG firm risk distribution $U(0,2)$. Under these assumptions, firms default if $\chi \varepsilon^{F}<R^{L}$, where $\chi$ is the probability of recovering collateral in the default state. The greatest lower band for the idiosyncratic shock at solvent firms is $\varepsilon^{F, M}$. Since the threshold depends on the loan rate, the probability of default is $\Phi=\operatorname{Pr}\left(\varepsilon^{F}<\varepsilon^{F, M}\right)=\frac{\varepsilon^{F, M}}{2}=\frac{1}{2} \frac{R^{L}}{\chi}$. Note however that with constant unit labour cost, $m c=R^{L}=(p m)^{-1}$, where $p m$ denotes the price mark-up. Hence, the probability of default in steady state can be written as $\Phi=\frac{(p m)^{-1}}{\chi}$, which depends only on the structural parameters of the model. Using the above conditions in the steady state loan rate equation derived from (15) yields,

$$
R^{L}=\nu\left\{R^{D}+\Delta\left(R^{V}+c-R^{D}\right)\right\}
$$

with $\nu \equiv\left[1-\frac{(p m)^{-1}}{\chi}\right]^{-1}>1$ denoting the constant risk premium under the above assumptions.

We rewrite equations (4) and (18) in their steady state form employing the above simplifying assumptions,

$$
\begin{gathered}
R^{V}=\frac{R_{t}^{D}}{\left(1-\xi^{V}\right)} \\
\xi^{V}=\frac{1}{2}(1-\chi) \frac{1}{\Delta} \frac{(p m)^{-2}}{\chi}
\end{gathered}
$$

Dividing (A1) by $R^{D}$ gives,

$$
\frac{R^{L}}{R^{D}}=\nu\left\{1+\Delta\left[\frac{R^{V}}{R^{D}}-1\right]+\frac{c}{R^{D}} \Delta\right\}
$$

Substituting (A2) and (A3) in (A4) results in,

$$
\frac{R^{L}}{R^{D}}=\nu\left\{1+\Delta\left(\frac{1}{1-(1-\chi) \frac{1}{2 \Delta} \frac{(p m)^{-2}}{\chi}}-1\right)+\frac{c}{R^{D}} \Delta\right\}
$$

or,

$$
R^{L}=\nu\left\{R^{D}+\Delta\left(\frac{(1-\chi) \frac{1}{2 \Delta} \frac{(p m)^{-2}}{\chi}}{1-(1-\chi) \frac{1}{2 \Delta} \frac{(p m)^{-2}}{\chi}}\right) R^{D}+c \Delta\right\}
$$

The following partial effects are immediate:

- A higher deposit rate $\left(R^{D}\right)$ raises the loan rate.

- A higher cost of issuing bank capital $c$ raises the loan rate. 
- A lower recovery rate $(\chi)$ raises the loan rate.

- A higher capital ratio $(\Delta)$ has an ambiguous effect on the cost of borrowing: as $c$ is very low, then the loan rate is decreasing in the capital ratio; for 'large enough' $c$ it is increasing. As mentioned in a footnote within the text, we find that for $c \geq 0.0014$ the loan rate is indeed increasing with the regulatory ratio. The value of $c$ chosen in our calibration puts the increase in the weighted average cost of capital and the cost of credit following an increase in bank capital into a reasonable empirical range, as well as fixes the long run loan rate at a plausible level. 